\title{
A configuração dos agregados como grupo social: marginalidade e peneiramento (o exemplo da cidade de São Paulo no séc. XVIII) *
}

\author{
Alzira Lobo de A. Campos \\ Mestre a História Social - FFLCH/USP
}

1. - O arranjo hierarquizado da sociedade paulista

O panorama que nos oferece São Paulo setecentista deixa entrever a imaturidade e o embrionarismo de sua sociedade. Herdados, segundo Sérgio Buarque de Holanda, da tibieza das formas ibéricas, caracterizadas pela fluidez de estrutura social e falta de hierarquia organizada. Os elementos anárquicos sempre frutificaram aqui, robustecidos pela cumplicidade ou a indolência displicente das instituições e costumes. (1)

As vicissitudes enfrentadas pelos primeiros povoadores, com o seu cortejo de emigrações e deslocamentos, os grupos distintos de habitantes que se foram estabelecendo na cidade ou em suas margens, à mercê das relações mantidas com indígenas ao longo dos primeiros séculos, constituíram fatores determinantes da gama variada do elemento povoador, refletida na ordem social. (2)

Dois fatores - importação de elementos anárquicos e critérios étnicos próprios - constituem o cerne do arranjo social de São Paulo. A eles deve ser juntada a extraordinária instabilidade geográfica e social da popu-

* Este texto constitui o capítulo VI da dissertação de Mestrado, Os agregados no tempo dos capitães-generais. O exemplo da cidade de São Paulo, apresentada ao Departamento de História da FFLCH/USP, sob orientação do Prof. Dr. Eduardo d'Oliveira França, em 1978.

(1) - Holanda, Sérgio Buarque de. Raízes do Brasil. Rio de Janeiro, Livr. José Olympio, 1956, p. 18.

(2) - Referindo-se especialmente ao elemento negro mas nem por isso deixando de lado índios e mestiços (a fortiori incluídos em um enfoque étnico), Roger Bastide e Florestan Fernandes afirmam que a cor foi em São Paulo um ponto de referência para situar os indivíduos na estruttura social, transparecendo na "anatomia" da sociedade escravocrata, mais ainda, intervindo, dinamicamente, em sua "fisiologia”. Cf. Brancos e negros em São Paulo. 3." ed. São Paulo, Ed. Nacional, 1971, p. 86. 
lação, cujos componentes intercambiavam-se com frequiência. A presidir a ordenação de grupos passavelmente delimitados, estava a estrutura econômica situada à margem do mercantilismo europeu, por isso mesmo estigmatizada pela pobreza e isolamento. Ainda sob esse prisma, as bases de compreensão da realidade não são sólidas. Observa bem Fernando Novais que a teoria mercantilista conformava-se mal à história concreta, passada mais no plano do atípico e do peculiar do que no quadro dos modelos. (3) Atípica e peculiar, certamente, era a sociedade paulista do século XVIII. Faltava-lhe uma atividade econômica suficientemente forte para embasar a organização social, como aconteceu, por exemplo, no Nordeste, onde o açúcar moldou a sociedade que cresceu em torno dele. (4) Os autores que trataram da história dos engenhos, dispuseram das funções inerentes à produção do açúcar para a visualização dos grupos sociais. Erigiu-se um modelo (turvado, embora, pelos contrastes vivos fornecidos pelo branco e negro, escravo e senhor), que serve de ponto de apoio para reformulações teóricas. A partir desse modelo é possível adotar-se posição crítica, à maneira de Stuart Schwartz quando se refere à simplificação da realidade operada por diversos estudiosos do Nordeste, os quais, inebriados pela miragem da "casa-grande \& senzala", esqueceram-se do artesão, do pequeno fazendeiro, do trabalhador assalariado, do branco pobre e do escravo alforriado. (5)

Para a história paulista, o problema metodológico agudiza-se, uma vez que, passado o tempo dos bandeirantes e não chegado 0 dos barões do café, os modelos construídos ressentem-se da falta de uma definição clara das lideranças sociais. As explicações historiográficas raramente são satisfatórias. A visão do anêmico período dos capitães-generais de São Paulo, após o restabelecimento da capitania, obscurece-se teoricamente pela atração exercida pelo Nordeste açucareiro, de um lado, e pelo bandeirismo, de outro. (6)

(3) - Novais, Fernando A. "Estrutura e dinâmica do antigo sistema colonial", Cadernos CEBRAP 17, São Paulo, 1974, p. 6.

(4) - "... For more than hundred years sugar ruled Brazil. From the end of the sixteenth to the beginning of the eighteenth century the cultivation of sugar provided Brazil with its raison d'être and shaped the society that grew around it" (Schwartz, Stuart B. Free labor in a slave economy: the lavradores de cana of Colonial Bahia; in Colonial Roots of Modern Brazil. Papers of the Newberry Library Conference, ed. by Dauril Alden. University of California Press, Berkeley, 1973, p. 6.

(5) - Ibid., p. 6.

(6) - A dificuldade, diga-se de passagem, não se restringe a São Paulo e com ela se defrontam os sociólogos de América Latina, obrigados a adequarem a uma situação histórica peculiar conceitua, categorias analíticas e interpretações pré-existentes. Diz Florestan Fernandes que o sociólogo latino-americano lida com realidades ao mesmo tempo difusas, complexas e altamente móveis, constatação que o leva a formular a questão: "Existem classes sociais na América Latina?" in: Capitalismo dependente e classes sociais na América Latina. Rio de Janeiro, Zahar Editores, 1973, pp. 36-37. 
O arranjo social desse período estava fortemente tisnado por critérios étnicos, que presidiram a uma divisão inicial da população. Certo, eses critérios não tinham individualidade própria, mas sim coincidiam com diferenças econômicas bem marcadas. (7)

Os documentos coloniais demonstram, mais do que mero preconceito, a necessidade de afirmação do grupo branco ("raça social"), hierarquicamente superior, sobre os demais componentes da população livre. Editais da Câmara procuravam fortalecer as distinções que corriam o risco de desaparecer entre brancos, negros forros, mulatos e índios. Várias sessões de vereança preocuparam-se em proibir o uso de armas - mesmo o do plebeu porrete - aos negros, mulatos ou carijós, acusados de "mortes e pancadas executadas com o dito instrumento os quais se divião evitar para mayor sucego e quietação do povo." (8) Os infratores estavam sujeitos a cem ou duzentos açoites, quer fossem negros, mulatos, índios ou "de outra qualquer nação", quando achados com "porretes de pau curto", de dia ou de noite. Além de açoitados cumpririam a pena de vinte dias na prisão, agravada pela perda da "baeta ou capote ou qualquer cobertura." (9) Esta última punição, além do sentido ostensivamente econômico, uma vez que toda a fortuna daqueles que assim delinqüiam poderia estar restrita à sua veste, parece carregar a intenção de aviltamento. De fato, um dos primeiros padrões europeus incorporados por índios e negros foi a indumentária, traço fácil para o discernimento de "selvagens" e "civilizados". (10) Os testamentos mostram a preocupação dos testadores em recobrir a nudez de seus protegidos, legando-lhes vestidos, de homem ou de mulher. Ainda em nossa época, entre os Guaranis, a manifestação mais evidente de miséria e de pobreza material é não ter com que se vestir. Egon Schaden diz que as roupas de tipo europeu tornaram-se necessárias ao índio, nem

(7) - Tulio Halperin Donghi, ao estudar tema similar na paisagem mais ampla da América Latina, emprega para os índios a definição de um pensador peruano que os chamou de "una raza social". Cf. Historia Contemporanea de America Latina. 3. ed. Madrid, Alianza Editorial, 1972, p. 39.

(8) - Documento n. 328, Revista do Arquivo Municipal, v. LXIX, São Paulo, 1941, pp 149-150.

(9) - Id., Ibid.

(10) - Pasquale Petrone, ao cuidar dos quadros da vida diária nos aldeamentos paulistas, refere-se ao vestuário como um processo de aculturação, através do qual o indígena adotou uma forma simples de cobertura do corpo, simples tanga de algodão ou, quando ia à vila, camisa e calça talhada em forma de ceroula. "Não sempre, entretanto, o indígena aldeado, especialmente a mulher, pode contar com uma verdadeira camisa ou um vestido camisolão de algodão. As referências aos indígenas que ficam, 'com suas mulheres, e filhos nús sem terem com $\mathrm{q}^{6}$ possão hir ouvir missa'..., ou daqueles 'impossibilitados $\mathrm{p.}^{\mathrm{a}}$ acodirem as suas mulheres, e filhos com o vistuario, q' por esta cauza trazem nús'..., são muito freqüentes para que constituam sempre apenas exagero em relação às condições dos indígenas. Quanto às crianças, tudo faz crer que vivessem a maior parte do tempo sem nada a co- 
tanto por the servirem de proteção, mas porque as suas relações com gente estranha exigem que o índio se apresente vestido:

"O índio 'pelado', o que não possui calças e camisa para cobrir a nudez do corpo, não sai de sua cabana, quando alguém visita a aldeia.

A roupa européia dá, pois, ao Guarani maior segurança de atitudes e capacidade de auto-afirmação diante do civilizado, que encara a nudez do índio como a expressão mais eloquiente de atraso cultural de selvageria”. (11)

Apesar da (ou devido à?) intensa miscigenação com os aborígenes, os paulistas melindravam-se com serem identificados com eles. Em 1725, os camaristas registraram seus protestos contra o ouvidor-geral que "... geral e publicamente, tratava aos paulistas de cabouclos, carijós e bêbados, e outros nomes, afrontozamente injuriozos." (12)

Embora a existência de tensões entre os diversos grupos étnicos envenenasse a vida em São Paulo, (13) as divisões raciais não eram estanques. A própria administração não parece ter levado muito a sério o caráter discriminatório da legislação. (14) É de Rugendas a observação de que

bri-las" (Os aldeamentos paulistas e sua função na valorização da região paulistana. Estudo de Geografia Humana. Tese de Livre-Docência apresentada à cadeira de Geografia Histórica, da Faculdade de Filosofia, Ciências e Letras da U.S.P. São Paulo, 1964 2v., mimeo., pp. 248-249).

A pobreza do vestuário, feito toscamente de algodão grosseiro, geralmente tecido pelos próprios indígenas, reforça a impressão de opróbrio contido no castigo de desnudamento dos faltosos.

(11) - Aspectos fundamentais da cultura Guarani. 3. ed., São Paulo, E.P.U.I EDUSP. 1974, p. 30.

(12) - Doc. n. 114, Revista do Arquivo Municipal, v. XIX, São Paulo, 1936, p. 8.

(13) - Os documentos atestam hostilidades entre os nascidos em Portugal e no Brasil, alicerçados por problemas competitivos. E o caso da petição de Jacinto José Frangeiro ao Sargento-Mor de São Paulo, na qual pede proteção contra Bento Alz' e seus filhos Antônio e Bento e genros José de Aguirre e Ventura Roiz, "pessoas de baixa esfera" com os quais se "inimistou" por problemas comerciais e que não teriam, segundo o Suplicante, dúvidas em lhe tirarem a vida, concorrendo para isto "a natural aversão que tem os nacionais/ e da qualld.e q. são os Supl.dos contra os filhos de Portugal o Supp te he" (Petição datada de 1772, In Requerimentos sobre dividas, heranças, queixas, licença, relaxação de prisão (1721-1820), ms, Caixa n. 91 (1721-1779), Arquivo do Estado de São Paulo).

(14) - Tullo Halperin Donghi chama a atenção para o problema étnico na América hispânica, dizendo: "...desde Montevideo, una fundación de aire tan moderno en ese Río de la Plata relativamente abierto a los vientos del mundo, en que un funcionario no logra, ni aun mediante una declaración judicial que atestigua la pureza de su sangre española, esquivar una insistente campaña que lo presenta como mestizo, y por lo tanto indigno de ocupar cargos de confianza, hasta Venezuela, en que la nobreza criolla, a través de algunos de sus miembros más ilustrados, se hace portavoz de resistencias más amplias al protestar contra la largueza con que las autoridades regias distribuyen ejecutorias de hidalguía a quiones tinen con qué pagarlas" (op. cit, p. 39). 
quando não existiam caracteres incontestáveis da raça africana, os homens de cor poderiam ser considerados brancos. "De há muito, no Brasil", dizia ele em inícios do século XIX, "caíram em desuso as leis que excluiam os mulatos de todos os cargos civis e eclesiásticos. Encontram-se homens de cor em todos os ramos da administração, no sacerdócio, no exército, e muitos há de excelente família". A cor, ainda segundo o mesmo Autor, não impedia a ascenção social, caso em que o indivíduo passava a ser registrado como branco, como ocorria em numerosos exemplos de homens de indiscutível ascendência africana ou índia e que ocupavam os cargos mais elevados. (15)

No plano das relações humanas, os contatos da massa trabalhadora, constituída de homens de cor, com os seus donos oscilavam da situação de dependente para a de protegido e até de solidário e afim. (16) As resoluções discriminatórias, ditadas pela Metrópole, faziam exceção no quadro geral da Colônia e tendiam a ficar no papel, sem perturbar seriamente a tendência da população para um abandono de todas as barreiras sociais, políticas e econômicas - entre os homens de cor. (17)

A complexidade do quadro étnico da capitania, pouco orgulho racial dos portugueses, contribuíram para a diminuição das barreiras étnicas entre os povoadores.

O quadro social, entretanto, apresentava-se bem mais complicado, como resultante de fenômenos de índole vária que atuaram ao longo da época colonial, alternando a organização primitiva e impulsionando sua evolução.

Nos primeiros séculos, as agruras da vida bandeirante, agravadas pelo isolamento e pela pobreza geral, alicerçaram uma espécie de "democracia igualitária" (18), que deve ser entendida como uma divisão mais ou menos equiitativa da miséria. Só após esse nivelamento inicial, é que se pode sentir a separação de níveis sociais, dominados por um grupo batizado por alguns autores de "aristocracia". (19)

(15) - A respeito, o episódio narrado por Rugendas sobre o mulato que teimava em não ver a mulatice de determinado capitão-mor ("Pois, Senhor, Capitão-mor pode ser mulato?") é bastante elucidativo, uma vez que comprova a barreira racial ao deixar claro que um mulato não poderid ser capitão-mor. Daí a estranha metamorfose registrada pelo Autor; $\mathrm{Cf}$. Rugendas, Johann Moritz, Viagem pitoresca através do Brasil, trad. de Sérgio Milliet. São Paulo, Martins/EDUSP, 1972, p. 76.

(16) - Cf. Holanda, Sérgio Buarque de, Raizes do Brasil. 3. ed., Rio de Janeiro, Livr. José Olympio, 1956, p. 54-55.

(17) - Op. cit., p. 55.

(18) - Como adverte Richard Morse, é evidente que o termo deve ser tomado nos estritos limites político-sociais da época (Formação histórica de São Paulo: de comunidade à metrópole. São Paulo, Difusão Européia do Livro, 1970, p. 3).

(19) - Ellis Júnior, Alfredo. Resumo da História de São Paulo. São Paulo, Tip. Brasil, 1942, pp. 77-78. 
Ainda no século XIX os viajantes observaram os curtos distanciamentos sociais que presidiam às articulações humanas. As raízes desse fenômeno mergulham em forças que deram ao planalto o seu particularismo: a tradição portuguesa, as dificuldades de comunicação, o pequeno valor econômico-financeiro dos núcleos de povoamento, o patriarcalismo atenuado, a policultura, a organização semi-militar, a autarquia econômica, as lutas contra inimigos externos e internos, nas quais os paulistas viramse abandonados pela metrópole... (20) No século XVIII a estagnação econômica (21) de São Paulo provavelmente abastardou muitas expressões da vida social. (22) Os distanciamentos entre diversos estratos pareciam insignificantes aos olhos de alguns viajantes. (23)

O esquema repetia-se fora da capital, onde os fazendeiros abastados levavam uma vida primitiva. Suas casas ostentavam o mobiliário mesquinho observado nos inventários dos séculos anteriores: catre de madeira e couro cru, mesa mal aparelhada e alguns bancos toscos. (24) O gênero de vida primava pela rusticidade: casas de apenas um andar, com paredes de taipa, algumas vezes caiadas; indumentária consistindo em uma camisa de algodão e calça do mesmo tecido, entre os homens, que andavam descalços ou com grandes tamancos muitas vezes munidos de esporas. As mulheres usavam apenas um camisolão de algodão branco, quando no interior das residências "e, em chegando um estrangeiro envolvem-se em um grande xale do mesmo tecido". (25)

(20) - Id., Ibid., p. 108-109.

(21) - Richard Morse insurge-se contra o emprego da palavra "decadência" relativamente a São Paulo do século XVIII, uma vez que por razões equivalentes poderia a época ser caracterizada como "de germinaçäo": "O que houve, foi que o século XVIII presenciou uma lenta mudança nos hábitos e atitudes que armou o palco para a junção de forças que produziria a metrópole" (op. cit., p. 35).

(22) - Canabrava, Alice Piffer. "Decadência e riqueza", Revista de História. São Paulo, 1974, p. 337.

(23) - "Há em São Paulo algumas casas verdadeiramente ricas; mas, em geral, as fortunas não são muito consideráveis... As casas, construídas de taipa muito sólida, são todas brancas e cobertas de telhas côncavas; nenhuma delas apresenta grandeza e magnificência, mas há um grande número que, além do andar térreo, têm um segundo andar e fazem-se notar por um aspecto de alegria e de limpeza", (Saint-Hilaire, Auguste de. Viagem à Província de São Paulo. São Paulo, Livr. Martins/EDUSP, 1972, pp. 162-156.

Rugendas atribui aos imigrantes espanhóis muitos dos hábitos adotados pelos paulistas: "... Donde, também, a grande simplicidade dos costumes dos paulistas, a ausência de luxo nas classes elevadas, principalmente no que diz respeito aos móveis e aos utensílios de cozinha; daí, também, essa cordialidade que reina nas suas relações sociais". (Op. cit., p. 80). XXVII.

(24) - Morais, Rubens Borba de. In: "Introdução" a Saint-Hilaire, op. cit., p.

(25) - Rugendas, op. cit., p. 114.

(26) - "... a polidez dos paulistas estende-se até às classes inferiores. As pessoas de posição cumprimentam-se mesmo quando não se conhecem" (op. cit, p. 169). 
O mesmo despojamento vigorava nas relações sociais. Cordialidade, simplicidade, polidez, notados por Saint-Hilaire e Rugendas, (27) parecem confirmar o passado democrático da sociedade paulistana, enfatizado por alguns historiadores. (28)

Não obstante, o tratamento igualitário vigorante entre superiores e inferiores - costume de longa duração na história paulista - situava-se ao nivel mais superficial do cotidiano, sem grandes aprofundamentos na ordem social. Ao mesmo tempo que provinha da rusticidade dos meios de vida, indicava a fluidez da estratificação social, não significando em absoluto falta de hierarquização. (29) Pelo contrário, segundo Maria Sylvia de Carvalho Franco, o caráter democrático expresso no trato entre membros de diferentes estratos sociais, serviu de instrumento de dominação, mascarando as distâncias sociais efetivamente existentes (30), fato que se confirma no contexto latino-americano, onde a porosidade da estrutura tradicional permitiu a absorção de elementos modernizadores, sem com isso perder a sua fisionomia. (31)

De resto, a visão emplastadora da população paulista, transmitida por documentos e por observadores diretos, sofre os primeiros abalos ao se compulsarem os recenseamentos coloniais. Neles encontra-se inventariada uma comunidade diversificada em grupos heterogêneos. E verdade que as divisões nem sempre são claras, uma vez que um dos critérios básicos para a estratificação social - a divisão do trabalho dada por funções especí-

(27) - "A liberdade que reina entre os senhores, em todas as suas relações e em todas as classes da sociedade, não lhes é menos propícia; ela diminui de muito os inconvenientes inerentes à escravidão" (op. cit., p. 133).

(28) - "Nenhuma preocupação de classes e posiçôes, igual tratamento para todos, a vida $\mathrm{em}$ contínuo perigo e um sentimento nítido de solidariedade social de que as atas da Câmara são o melhor testemunho. ... A população do planalto primou sempre pelo seu sentimento operário. Todos os habitantes de Piratininga eram operários. ... Pero Leme foi um modesto carpinteiro, assim como Braz Esteves e Bartolomeu Bueno. Ferreiros foram Clemente Älvares ... e Domingos Fernandes, o fundador de Itu, Sapateiro foi Baltazar Gonçalves, fura-mato incorrigível e renitente. Diogo de Quadros era fundidor de ferro. Amador Bueno fabricava chapéus e Afonso Sardinha foi Operário agricola, além de minerador. ... Etnicamente, intensa mestiçagem com aborígenes, da qual resultou o mameluco dominante nas arrancadas. Isto é, encurtamento das distâncias sociais pela mestiçagem" (Ricardo, Cassiano. "O negro no bandeirismo paulista", Revista do Arquivo Municipal, v. XLVII, São Paulo, p. 36.

(29) - Franco, Maria Sylvia de Carvalho, op. cit., p. 72.

(30) - Id., Ibid., p. 72.

(31) - Morse, Richard M. "Formação histórica de São Paulo", p. 22. Como embasamento dessa afirmação, o Autor cita um trabalho (Comisión económica para América Latina. El desarrollo social de América Latina en el posguerra. Buenos Aires, 1963, pp. 12-13), que contesta a tese segundo a qual as sociedades tradicionais são como cascas mais ou menos endurecidas, podendo apenas resistir ou quebrar-se em pedaços. Ora, são a flexibilidade e penetrabilidade dessas sociedades que favo. recem a permanência de seus padrões tradicionais. 
ficas - baralhava-se pela polivalência ocupacional dos moradores. Do mesmo modo, os julgamentos de valores sociais, pelos quais os homens se avaliam mutuamente e determinam a posição de cada um na escala social (32), não são facilmente discerníveis à distância. Como compreender os critérios sempre mal definidos, vagos e mais ou menos inconscientes que presidiam à hierarquização de São Paulo setecentista? A prisão do tempo, com seus condicionamentos fornecidos por preconceitos, valores e maneiras de pensar específicos, torna ingrata a tarefa de imaginar um mundo diferent edo nosso, no passado ou no futuro. Os mecanismos valorativos da sociedade colonial são estranhos à nossa época. É difícil apreendê-los. (33) No entanto, exerceram a função de enquadrar os homens em uma organização avessa aos formalismos. As tentativas de ritualizar as relações sociais, na sociedade pioneira do planalto, aparecem como esdrúxulas e sempre recessivas. Ocorreu, em São Paulo, uma verdadeira desmoralização dos privilégios peninsulares, fato que deve ter sido doloroso para os privilegiados. É o que se adivinha na carta abaixo, cuja transcrição, um tanto longa, justifica-se pela brecha que fornece ao estudo da mentalidade da época. Tal documento chega a provocar vertigens pelos meandros das palavras e idéias expostas por um homem cioso de sua posição hierárquica, em luta aberta contra as tendências igualitárias dos moradores.

"A falta de practica das Cameras, desta Capptna., e variedade dos ministros, que nella servirão athe o prezente tem emtruduzido diferentes estilos na forma de se levar o estandarte naprocição do Corpo de Deos e nas mais que se fazem com a denominação de reais. e paresse perciso regularsse esta formalide. e para que senão falte ao reverente respeito e veneração, devida a ral insignia e se evitem os endecorosos arbitrios da ignorancia alguns ministros antes de haver governador nesta cappna. e já depois de o haver quando, não asistem nas procisõis custumarão levar o estandarte no meyo da fileyra que forma o corpo da Camera outros no lado direyto e primeiro lugar da mesma fileyra, e o desvanesimento do ouvidor Francisco Galvão entroduziusse adeantarsse elle ao Corpo da Camera, com o estandarte a sua mão direyta erro de sua loucura, porque nem o ouvidor deve alargar o lugar primeiro da fileyra, da Camera como prezidente della nem tomar o lugar

(32) - Housnier, Roland. Les hiérarchies sociales. De 1450 à nos jours. Paris, Presses Universitaires de France. 1969, p. 6-7.

(33) - "Les jugenants de valeur sociaux ... proviannent non d'idées et de constataions précizes mais de croyances, d'impressions, d' opinions, le plus souvent su.ggérés par des émotions, des tendances sentimentales et affectivas, perfeitement irrationneles et largement erronées. Et c'est ainsi que naissent et s'établissent les Jugements de valeur sur l' utilitá plus ou moins grande de telle ou telle fonction sociale, sur la capacité plus ou moinz grande de tel ou tel homme, de tel ou tel groupe, de tel ou tel corps à remplir cette fonction. C'est ainsi que s'édifie une part importante des structures fondamentales de toute sociéte" (op. cit., p. 7). 
do governador que the he emcompetente - Igualmente he erro levar o estandarte, no meyo da fileyra do corpo da Camara ou no primeyro lugar do lado direyto da mesma fileyra porque sempre o estandarte deve preseder a Camera na forma que precede o governador a Camera quando o governador asiste na procição vay logo atras do palio leva o estandarte $\circ$ mão direyta $\mathrm{e}$ dous passos atras vay o Corpo da Cama. com o mo. que prezide, e pode ser decorozo, e acertado, que quando o governador não vay na pocição demenua o estandarte da regalia, e da prezidencia de hir logo atras do palio, e que se vá encorporar com a Cama, a ombreando com a mão dereyta do ministro prezidente -: de sorte que quando o governador vay na pocição se hade adeantar o estandarte para hir na fileyra da Camera! por este modo não se poderia negar que o governador enfunde preeminencia no estandarte e que este sahindo da fileyra da Camera vem fazer o obzequio ao governador em se por ao seu lado; nos exercitos leva o estandarte do general o lugar mais preheminente da primeira linha, o real estandarte de vossa Mage. se o governador não for na procição não meresse o primro. lugar preferindo a Cama. prefere o governador a Camera, mas o estandarte não the hade preferir! Esta sega barbaridade. só se pratica neste inculto sertão, e pa. se emendar e obviar juntamente as controvercias, e questois que os ministros poderão de futuro, levantar paresse emportante que vossa magestade haja de ordenar regestando-se a rezolução, nesta enas mais Cameras da cappna. que quando o estandarte vem na Camera para a Igreja e volta desta pa. a Camera se leve o estandarte dous ou tres passos diante, e que o corpo do senado e mais cidadois o sigão atras e nas prociçois vá logo emediato ao palio acista, ou não acista, o governador e o mesmos dous, ou tres passos afastado o corpo da cama. Sãm Paulo 8 de junho de 1731. Antonio da Sylva Caldra. Pimentel". (34)

Este documento sugere a importância assumida por valores não diretamente ligados à economia, quando se tratava de ostentar posições hierárquicas em ato público, hipótese na qual vigoravam paradigmas europeus, consubstanciados em leis e costumes estranhos ao meio rústico paulistano. E óbvio que cedo a realidade colonial provocou distorções no modelo português, mas a permanência teórica desse modelo criou injunções e adaptações que se não podem desprezar e que suscitam a necessidade de estudá-lo.

Para o Direito Público Português do século XVIII e início do XIX, o conjunto da população constituía-se pelos "naturais do Reino", assim

(34) - Registro de húa curta do doutor ouvidor gal. e mais documtos. sobre a forma em que deve hir a bandra. da Cma, nas prosisõis reays. Doc. n. 88. Revista do Arquivo Municipal, LI, São Paulo, 1938, pp. 72-73. 
subdivididos: a) portugueses; b) os nascidos nas colônias portuguesas; c) os meninos expostos dentro de Portugal. (55) Só a partir da ascensão do Brasil ao vice-reinado, os aqui nascidos foram equiparados aos primeiros (Lei n. 16, de 16/12/1815). (36) Essas categorias eram formadas, grosso modo, por nobres e plebeus. Os fidalgos eram os que tinham seus nomes assentados nos livros da Casa Real (afilhados ou afeitos ao serviço del Rei); os que o Rei por mercê como tal os declarava; os filhos e netos destes últimos e daqueles primeiros. O fidalgo podia ter foro de moçofidalgo, de fidalgo-escudeiro, de fidalgo cavaleiro e outros mais." (37)

Nobres eram também considerados os clérigos, os desembargadores, os oficiais da justiça do rei, os vereadores, os militares, os canonistas, os doutores "in utroque jure", e os médicos (físicos). As artes liberais também nobilitavam: assim os cirurgiōes que não fossem também barbeiros, os pintores e os ourives. (38)

Provavelmente no tempo de Melo Freire e Pombal, o título de nobre estendeu-se aos comerciantes atacadistas.

Foi essa nobreza peninsular que produziu a brasileira. Ambas bastante duvidosas, uma vez que os títulos de fidalgos, os hábitos de ordens militares e em geral a nobreza de segunda ordem, tinham, como informa Coelho da Rocha, perdido muito da antiga consideração, desde os tempos de Filipe II. O estrato médio ou se não julgava inferior ou se supunha igual ao nobre. (39)

A arraia miúda representada por plebeus e peões, eram os que trabalhavam por jornal, os mecânicos, os barbeiros, os mercadores varejistas e outros.

O nobre, se exercesse ofício de mecânico, perderia o título e as suas prerrogativas. (40)

(35) - Carneiro, Borges. Direito Civil Português, v. II, p. 72, apud Almeida, Fernando Mendes de "O folclore nas Ordenações do Reino. In: Revista do Arquivo Municipal, v. LVI, 1939.

(36) - Almeida, Fernando Mendes de op. cit., p. 91.

(37) - Id., Ibid., p. 92.

(38) - Id., Ibid., p. 92.

(39) - Rocha, Coelho da. Ensaio sobre a história do governo e da legislação de Portugal, 1872, apud Almeida, Fernando M. de, op. cit., p. 93.

(40) - Alberto Sampaio (Estudos Históricos e Econômicos. I. Porto, 1923, p. 248) observa, no entanto, que "... como a lei consignada nas Ordenaçōes confessa que havia homens da linhagem dos Filhos d'algo em todas as profissões, desde os oficiais industriais, até os arrendatários de bens rúsicos; unicamente lhes são negadas as honras enquanto viverem de trabalhos mecânicos. A comida do povo - declara ainda - não se distinguia muito da dos cavalheiros nobres, por isso que uns e outros estavam em contínuas relações de intimidade; não só os nobres comiam com 
Embora a lei portuguesa sempre tenha encontrado dificuldade ao ser aqui aplicada, foi ela que forneceu os quadros aos quais se amoldaram as novas condições de vida do planalto. Sérgio Buarque de Holanda alega a respeito que os contatos com raças indígenas ou adventícias não nos fizeram tão diferentes dos nossos avós de além-mar. De Portugal recebemos a forma atual de nossa cultura, acrescentada de matéria que se sujeitou bem ou mal a essa forma. (41)

Documentos oficiais permitem que se acompanhe a distorção sofrida pelos modelos importados do Reino, quando aplicados à realidade colonial. Estabeleceu-se uma filtragem lenta, porém segura, dos padrões metropolitanos, traduzidos em uma imagem pouco fiel da sociedade portuguesa, à qual contrapunham-se os capitães-generais, revelando tendências vãs para aproximar a cópia do original. Por exemplo, quando se tratava de expressar hierarquias do novo mundo, o modelo manipulado pelos administradores era o reinol, o único que teoricamente conheciam. Daí o aturdimento que esse proceder provocava nos cidadãos, ignorantes do rang no qual a ideologia metropolitana os situava.

Essa idéia é ilustrada pelo episódio que se seguiu ao alvará de $17 / 1 / 1715$, pelo qual $D$. João $V$ nobilizou os paulistas que servissem como juizes ordinários, vereadores e procuradores do Conselho. (42) Desvanecidos com a mercê real, mas ignorando a sua significação, os camaristas paulistanos consultaram seus pares do Rio de Janeiro, usando termos vasados em humildade e singeleza:

"Sua Majestade que Deus guarde dignou-se de nos fazer honra e mercê conceder-nos os privilégios de que gozam os oficiais da Camara da cidade do Porto de que já lhe rendemos as graças como gratos e obedientes vassalos, suposta a nossa inferior capacidade.

$\mathrm{E}$ como os ditos privilegios são in genere os mesmos, que os desse nobilissimo Senado, quizeramos que vossas mercês não lhes sendo de molestia, nos remetessem a copia deles em forma judicial para delles nos podermos valer; em as concessões precisas, que tambem em outras quaisquer que forem do agrado de vossas mercês nesta cidade não faltaremos com a urbanidade." (43)

os populares, mas ainda thes entregavam a criação dos filhos. Prova está na instituição do amédigo pela qual os nobres davam a educar seus filhos aos vilãos, que desfrutavam, nesse caso, de alguns privilégios e isenções" (Citado por Holanda, Sérgio B. de. Raízes do Brasil, p. 23).

(41) - Op. cit., p. 5.

(42) - Taunay, Affonso de E. "Privilégios setecentistas dos cidadãos de São Paulo", Revista do Arquivo Municipal, v. VIII, São Paulo, 1935, p. 4.

(43) - Op. cit., p. 5. 
O que parece incontestável, portanto, é que no sistema social, complexo e pouco hierarquizado de São Paulo, a posição de uma pessoa era determinada por nascimento, laços de família, ocupações, bens possuídos e funções desempenhadas na administração civil, militar ou religiosa. Por outro lado, a estratificação das diversas camadas não era rígida. As diferenças entre "nobres" e "mecânicos" mantinham-se dificultosamente, face à pobreza geral. A plebe, camada inferior da população, abrigava os trabalhadores comuns, sem diferenças abruptas entre livres e escravos. (44)

Teoricamente, os mecânicos, os cristãos-novos e os que tivessem parentesco com outros oficiais do governo estavam impedidos do exercício dos cargos da república. Na prática, não obstante, nunca chegou a ser vedada com rigor a ascensão desses elementos a lugares eminentes. (45)

Recrutado por processos vários e casuísticos, um grupo exercia o comando sobre a massa populacional. Elite ou aristocracia (não é de interesse, aqui, precisar o rótulo) (46) inspirou algumas descrições como esta:

“... gostavam de vestir-se bem e eram zelosos de fidalguia e nobreza, que não davam suas filhas para casar aos que depois vinham (os do Reino) sem que fizessem as justificações necessárias de nobreza, de branco e de cristão velho, por cujo motivo os arquivos das Câmaras da cidade de São Paulo e vilas, estão cheios destes documentos. Eram largos em gastos, possuiam bom gosto e sentimento artístico, com ten dência para o luxo, como consta nos 'Inventários', apreciavam a boa mesa, louças, prataria, não possuindo muitos móveis”. (47)

(44) - Cf. Morse, Richard, op. cit., p. 33.

(45) - "Pode-se afirmar que se acham, em geral, mal delineadas as fronteiras que separam da 'nobreza' os do povo, de sorte que sobem, muitas vezes, os últimos a lugares teoricamente reservados àquela, e também não se pejam os nobres exercer ocasionalmente ofícios tidos por indígnos de seu status". (Holanda, Sérgio B. de. Movimentos da população em São Paulo no século XVIII, pp. .64-65).

(46) - "Aristocracia é um pequeno grupo social que, por hereditariedade, modo de vida, educação, gosto requintado e linguagem, se distingue da massa. A aristocracia associa-se, quase sempre a uma situação privilegiada de fortuna. - . . o que distingue, em todo caso, o aristocrata $́$, antes de mais nada, certa forma de linguagem, certo modo de comportamento, certa independência de fortuna, certo sentimento de classes ou casta. ...A elite é forçosamente uma minoria, mas não é este caráter de minoria que a diferencia, porquanto nem todas as minorias são em regra geral elites. Não seria mesmo possível definir uma elite unicamente pelo caráter social de minoria. ... Uma elite é, pois, um grupo de personalidades fortemente marcadas, bem distintas umas das outras e cujo único traço comum é uma consciência lúcida das necessidades do meio social em que vivem e da maneira pela qual é preciso corresponder a estas necessidades... A elite é, de fato e antes de mais nada, composta de personalidades fortes e capazes de agir sobre os grupos, animá-los e orientá-los" (Bastide, Paul Arbousse - "Cultura, aristocracia, elites", Revista do Arquivo Municipal, v. XVI, São Paulo, 1935, p. 92-94).

(47) - Campos, Dulce, op. cit., pp. 10-11. 
As justificações de nobreza identificam caracteres classificatórios. Em 20 de fevereiro de 1794 o Mestre de Campo Agostinho Delgado Arouche apresentou um instrumento civil a respeito:

"3\% Item que o ditto seu Pay o Sangentomór Francisco Nabo Freire, sempre se tractou a Ley da Nobreza, nunca exercitou Officio algum mechanico, antes em a Villa de Guaratinguetá desta Capitania, onde se estabelleceu logrou athéa sua morte o mayor respeito tratandose sempre com o tratamento devido a sua Pessoa por ser a sua caza huma das mayores em riqueza naquella Villa, o qual he da principal Nobreza da Ilha de Lagos ... 6. Item que o Justificante por parte de sua May Dona Pires de Barros Leite descende legitimamente sem quebra de bastardio ou machanismo das Illustres Familias dos Pires, Barros, Pedrosos, Mesquitas, Bicudos, Leytes, Brittos, e Lemes, que são da primeira Nobreza desta Capitania." (48)

Vias certas de ascensão social constituíam portanto a ascendência ilustre, a riqueza, o prestígio social, o respeito, o não exercício de ofícios mecânicos. (49) Desses, a riqueza constituía fator dominante, incontornável. Estruturou-se, asim, uma sociedade baseada na subordinação de homens sem recursos e de escravos a senhores poderosos - grandes comerciantes, proprietários de terras, de gado ou de ouro. (50) Os níveis de riqueza classificavam as pessoas no período do "grande recesso econômico da Capitania Paulista, no século XVIII". (51) Os cabedais revelados pelas listagens de população traduzem uma concentração exacerbada de riqueza em mãos de uns poucos, enquanto que mais da metade da população livre nada possuía (um levantamento referente ao período de $1765 / 7$, acusa a porcentagem de $54,94 \%$ de habitantes situados na faixa de riqueza de 0 a 50-000). (52) Os homens de negócio eram os que apresentavam os mais altos índices de riqueza na cidade de São Paulo. Os ápices, nos cabedais anotados, andavam em torno de vinte contos de réis, não chegando a trinta, com a riqueza média de aproximadamente $2: 794 \$ 000$. (53)

Os mercadores e homens de negócios eram na maior parte reinóis:

(48) - Instrumento civil de justificação de nobreza, apresentado pelo Mestre de Campo Agostinho Delgado Arouche. DI, v. XVI, pp. 181-202.

(49) - Critérios que se repetem momentaneamente quando se trata de honrar uma pessoa: “... sendo a dita Dona Marta huma viúva ônesta e das principais familias desta Capitania, e muito abonada". Contido em denúncias contra o ouvidor geral, em 11/8/1725. Doc. 119, Rev. Arq. Mun. v. XIX, São Paulo, 1936, p. 86.

(50) - Bruno, Ernani Silva História do Brasil, Geral e Regional. São Paulo e o Sul. Vol. V. São Paulo, En. Cultrix, 1967, p. 64.

(51) - Canabrava, Alice P. Op. cit., p. 355.

(52) - Op. cit., p. 351.

(53) - Op. cit., p. 352. 
"Os vindos do Reino, escreverá o Marquês de Lavradio, Vice-Rei do Rio de Janeiro, não cuidam em nenhuma outra cousa que em se fazerem senhores do comércio que aqui há e não admitirem filhn nenhum da terra a caixeiros por onde possam algum dia serem negociantes; e daí abrangerem em si tudo que é comércio." (54)

Os artigos importados, especialmente peças de vestuário, eram indispensáveis para a manutenção do prestígio social, muito ligado, na época, à aparência. D. Luiz Antonio de Souza Botelho Mourão denunciou o emprego excessivo de capitais paulistas na aquisição de mercadorias inglesas:

"A sombra destes trabalhos vem a Inglaterra, sem susto nem despesa, desfructar tranquilamente o melhor, e mais puro cabedal de todos estes habitantes, porque adormecidos na natural occiozidade, e recostados no descanço da sua mal antendida vaidade, pagão fielmente nas Tendas, e Longeas de negocio (que se compoem pela mayor parte de effeitos Estrangeiros) tudo quando os seus escravos diariamente lhes ganhão, e tirão nas suas Lavras, ficando ainda em cima empenhados para nunca possuirem de seu um só vintem, porque não falando nos comestiveis, e fazenda de fora do Reyno, que comprão os Povos, que hé couza muito avultada, falarei so particularmente no calculo do que gastavão os negros, os quaes computados a $3 \$ 500$ r.s. cada anno de surtum, baeta, bombachas, sendo os negros 23.323, soma o gasto $81.530 \$ 500$ r.s., de que vay a mayor parte para a Inglaterra, com os mais que gastão os brancos, e todos os habitantes livres." (55)

Viviam os habitantes da "nobre e Leal cidade de S. Paulo", com "a abundância de seus propios Cabedais ... Com todo o Lusimento, a Lej de Nobreza". (56) Luzimento com certeza menor do que aquele verificado por Frei Manuel Calado em Olinda, onde, entusiasmo retórico descontado,

“as mulheres andavam tão louçãs, e tão custosas, que não se contentavam com os tafetás, chamalotes, veludos, e outras sedas, senão que arrojavam as finas telas, e ricos brocados; e eram tantas as jóias com que se adornavam, que pareciam chovidas em suas cabeças, e gargantas as pérolas, rubís, esmeraldas, e diamantes." (57)

(54) - Prado Júnior, Caio - Formação do Brasil contemporâneo. Colônia. 5. a ed. São Paulo, Ed. Brasiliense Ltda., 1957, p. 278

(55) - Carta de D. Luiz Antonio ao Conde de Oeiras (22/2/1769). Documentos Interessantes, v. XIX, pp. 282-283.

(56) - Registro de huma carta que os Oficiais da Camara escreverão a Smagde, que Deos gde. (20/7/1725), Doc. n. 128, Rev. Arq. Mun., XX, São Paulo, 1936, p. 47 .

(57) - Calado, Manoel, Mestre Frei - O valoroso Lucideno o triunmpho da liberdade. Primeira parte. Primeiro tomo: I, II e III livros. 2." ed., São Paulo, Edições Cultura, 1945, p. 39-40. 
Repassada de romantismo podemos ler a descrição da cidade de São Paulo fornecida por Dulce Campos:

"Pelas ruas e logradouros, naquele dia festivo circulavam fidalgos vestidos de redingote de seda e calçōes justos, de cores vistosas, predominando o escarlate e o verde gaio, calçados de meias brancas, com sapatos de enormes fivelas de prata, algumas carregadas de gemas. Traduziam sob os tricórnios de seda, deixando à mostra as empoadas cabeleiras de carrapito ou trancinhas à chicote, com finos espadins ao lado esquerdo e bastões ou bengalas de ricos castōes; muitos acompanhavam morenas esbeltas, de olhares esquivos, arrastando saias balão de veludo e seda, com largos decotes, cobrindo-se com rendilhadas mantilhas negras alteadas por pentes de tartaruga. Cumprimentavam de mergulho, tratando-se solenemente de primos. Algumas mulheres de capas, mantos e jozesinhos vermelhos de gola e capus confundiam-se com outras muito embuçadas em baetas pretas, com chapéus de castor nas cabeças e rosto quase tapados. Eleciásticos e frades passavam conversando com homens rudes de largos chapéus de couro e botas altas com esporas cantantes; outros embrulhados em vastas capas, com militares de farda azul, recamadas de botóes de prata. Às portas das boticas e das lojas, negros vestidos de baeta acotovelavam-se com mamelucas que arrastavam crianças, vendo passar com quela gente, raras serpentinas e cadeirinhas de damasco escarlate sustidas por negros fortes. Para os lados da Cadeia, no Caminho de Ibirapuera estacionavam banguês entre o chiar de carros de bois que chegavam ..." (58)

A aristocracia que vemos repontar no quadro acima, compunha-se, além dos homens de negócio (59), de funcionários da administração, de proprietários de terras, de agricultores, de mineiros, de sacerdotes. Uma lista de provedores de Irmandade da Santa Casa de Misericórdia de São Paulo, no período de 1700 a 1822 , constitui fonte segura para o conheci-

(58) - Campos, Dulce - O governo..., p. 9-10.

(59) - A importância dos comerciantes na época colonial não foi ainda convenientemente explorado pela nossa historiografia, ainda muito presa aos proprietários rurais como a "nobreza da terra". Sobre o assunto diz Sérgio Buarque de Holanda: “... Em verdade, verdade que é oportuno frisar, as élites do Primeiro Reinado vêm bre uma doença infantil da Historiografia. (Final), "Suplemento Literário. O Estado bem mais da classe dos comerciantes urbanos do que da aristocracia rural ..." ("Sode São Paulo. São Paulo, Ano XVIII n. ${ }^{\circ} 830$, p. 6). Na cidade de São Paulo, a presença dos negociantes era notável, como se verifica nos moços da população. Um quadro-resumo não datado mas contido na Caixa 31 referente ao período de $1779 /$. 1794, registra o número de 401 negociantes, o maior entre as ocupações anotadas. Esse mesmo documento mosta que a renda anual da cidade, foi de $67: 443 \$ 200$ para o comércio e de apenas $36: 937 \$ 740$ para a agricultura. AE. Ns. 
mento das ocupações exercidas pelos membros da elite citadina. (60) Pertencer a essa instituição dava foros de nobreza, daí a atração que a Santa Casa exercia sobre a anêmica aristocracia da terra. (61) Em ocupações ligadas à economia aparecem

"grande proprietário, com muitos índios e escravos negros; sertanista; fiador do contratador do subsídio dos vinhos e azeites; dono de grande fortuna; descobridor de minas; agricultor; usurário; bandeirante; enriquecido nas minas; contratador de carne; dono de sesmarias; negociante rico; arrematador de dízimos de Cuiabá; homem de negócios; possuidor de considerável fortuna; arrematador de contratos, como o do sal; comerciante rico; negociante; comerciante; cirurgião-mor”. (62)

Quanto aos ocupantes de cargos da administração civil, militar ou eclesiástica encontram-se:

"juiz de órfãos; governador substituto; capitão-mor; governador; cargos públicos diversos; vereador; capitão; sargento-mor; juiz ordinário; procurador do conselho; ouvidor; corregedor da capitania; guarda-mor; sesmeiro; provedor dos quintos reais; procurador da Coroa; procurador da vila; escrivão da Câmara; cobrador do Donativo Real; guarda-mor das minas de São Paulo; procurador; capitão-mor das minas de Goiás; intendente da Capitação dos reais quintos; escrivão; mestre de campo; tesoureiro do Donativo Real; tesoureiro da Bula da Santa Cruzada; capitão-mor de ordenanças; capitão de ordenanças; sargento-mor de ordenanças; juiz; tabelião; almoxarife da Fazenda Real; alferes; inquiridor, contador e distribuidor da cidade de São Paulo; almoxarife, tesoureiro da Real Casa de Fundição de São Paulo, ajudante de ordenanças, capitão-general; bispo; arcediago; cônego; tenente-coronel; praticante, escriturário, deputado e escrivão da Junta da Fazenda." (63)

Esclareça-se que os cargos e profissões eram cumulativos: o mesmo provedor exercia duas, três e até mais funções concomitantemente.

Nas camadas medianas da população estavam os taverneiros e vendeiros, encarregados do comércio miúdo de beber e de comer. Tinham a riqueza média de $106 \$ 640$. (64) Os artesãos atingiam níveis de rendas

(60) - Mesgravis, Laima - A Santa Casa de Misericórdia de São Paulo (15991884). Contribuição ao estudo de assistência social, no Brasil. São Paulo, Tese de Doutoramento apresentada ao Departamento de História da FFLCH da USP, 1972.

(61) - Cf. op. cit., pp. 58-61.

(62) - Cf. Mesgravis, Laima - Op. cit., p. 61, Só foram citadas as ocupações uma única vez, a não ser quando adjetivos poderiam presumir um escalonamento da riqueza.

(63) Op. cit., p. 61.

(64) - Canabrava, Alice P. Op. cit., p. 358. 
relativamente altos e atendiam às necessidades mais imediatas da população. Muitos deles, porém, quase nada possuíam. (65).

No campo os donos de engenho de açúcar e aguardente seriam os melhor situados:

\begin{abstract}
"Contudo, não se tratava, em geral, de pingues fortunas, pois, referindo-se à Vila de Santos e de São Paulo, escrevia o Morgado de Mateus, 'não haver sujeito que possa servir para Mestre de Campo; em São Paulo há dois ou três somente, que suposto não têm todos os requisitos necessários, poderão remediar.'" (66)
\end{abstract}

Finalmente, misturando-se com os próprios escravos, estava a ralé imensa dos indivíduos sem ocupação alguma ou de ocupações incertas e aleatórias. Engendrados pelo próprio sistema colonial, destitúdos de recursos materiais, ia avultando com o tempo o número dos desclassificados socialmente. (67)

Conclui-se afinal que no tratamento das diferenciações sociais têm sido invocados critérios diversos: a cor, a ascendência ilustre, a posse de cargos públicos, atividades ocupacionais na cidade ou no campo. Numa sociedade escravocrata, porém, uma classificação mais válida deveria fundamentar-se nas diferentes definições jurídicas dos habitantes, ligadas por sua vez às várias situações sociais e econômicas, em geral intimamente relacionadas às primeiras. Assim, a posse da liberdade poderia ser o módulo da gradação social. Uns não a tinham de todo: eram os escravos, que constituíam massa geralmente indiferençada. A condição de homem livre representaria o caráter ordinário, básico, em função do qual se estratificava o todo social. A combinação da liberdade com privilégios de várias naturezas distribuíria seus possuidores nos diversos níveis sociais. Os mecanismos de cerceamento da liberdade ou a usura na partilha dos diversos privilégios induziam à formação dos grupos menos dotados, de tal forma que a carência total de privilégios respondia pela sedimentação dos grupos mais inferiorizados na escala social, obrigando-os a tais dependncias que chegavam a roçar a condição de escravizados.

(65) - Loc. cit.

(66) - Id., Ibid. p. 359.

(67) - Elizabeth Almeida vê a população da Capitania de São Paulo, na segunda metade do século XVIII, dividida em três estratos, cada qual com vários segmentos: I. - Estrato Inferior formado por pequenos agricultores, jornaleiros, agregados, pequenos comerciantes, tropeiros, pescadores, oficiais mecânicos, oficiais artesanais, pessoas carentes de recurvos. 2. - Estrato médio: criadores, donos de tropas; negociantes, profissionais liberais, militares, funcionários, clérigos. 3. - Estrato superior: senhores de engenho, membros do alto clero e alguns grandes negocianees. Cf. As elites na sociedade paulista na segunda metade do século XVIII, p. 87. 


\section{2. - Areas marginais, "viveiros" de agregados}

O estudo dos agregados denota que eles estavam relacionados intimamente com setores marginalizados, originários dos próprios descompassos da sociedade. Com etiologia evidentemente histórica, esses descompassos manifestaram-se em três níveis principais:

$\left.1 .^{\circ}\right)$ Ao nível social, as características étnicas, culturais e jurídicas dos habitantes condicionaram determinados padrões de valores e de normas que só poderiam ser plenamente adotados por uma minoria. Grosso modo e sem esquematismos rígidos, os livres - brancos ou mestiços -, detentores de algum capital ou de profissões inatingíveis pelos escravos, eram aqueles realmente aptos para o preenchimento dos papéis exigidos pela sociedade e, como tais, nela integrados. $O$ processo de socialização que levaria as populações marginais a se integrarem plenamente no mundo que as circundava foi travado ou impossibilitado pela ordem escravista. Esse esquema manteve uma camada - formada por forros, índios aldeados, brancos sem recursos, bastardos e outros - pouco ajustada à ordem social $\mathrm{e}$, portanto, sujeita à agregação.

$\left.2 .^{\circ}\right)$ Ao nível do sistema econômico configurava-se uma estrutura produtiva fechada, com poucos acessos e aberturas. Tal fato significou que boa parte da população viu-se obrigada a competir com a mão-de-obra escrava, sobrevivendo precariamente, numa situação de subemprego, com remuneração intermitente (por exemplo, os arrolados como jornaleiros), sem ocupação definida (tais como os "moradores novos") ou sem ocupação alguma (como os vadios que tanto preocupavam as autoridades). As condições vitais de sobrevivência estavam seriamente afetadas pela precariedade do sistema econômico de São Paulo, nas últimas décadas do século XVIII. A população enfrentava numerosas e variadas dificuldades: fome, epidemias, penúrias, falta de numerário, sistema de produção pouco elástico, estagnação econômica. Em resumo, crises de subsistência que respondiam pela subprodução e pelo subconsumo.

Os arquivos guardam testemunhos a respeito. (68) A 13/12/1766, o Morgado de Mateus, em carta ao Conde de Oeyras, declarou-se desen-

(68) - "A capitania de São Paulo, sendo a mais antiga de todas as do Brasil, se acha no miserável estado em que se vê" (Marechal Arouche, "Reflexões sobre o estado em que se acha a agricultura na capitania de São Paulo. $2 .^{\circ}$ semestre de 1788." Documentos interessantes, v. 44, p. 195).

"Tão bem devo ponderar a V.Ex." que sem se procurarem augmentar novos rendimentos não se pode ressuscitar esta Capitania morta que está falta de todo o necessário para sem aumento, a conservação, porquanto não ha caminhos tratovais, e necessita de se fazerem para poder girar negocia..." (Carta de Mergado de Mateus ao Conde de Oeyras, datada de 6/12/1767, Documentos Interessantes, v. 19, p. 99).

“... a falta de cultura nesta Capitania parte procede por falta de gente à proporção das terras, parte por demasiada preguiça dos habitantes, e huma grande parte 
ganado com o estado da capitania, afirmando que seus habitantes "são geralmente os mais pobres que alimenta a natureza", além de construir uma imagem elucidativa da pouca elasticidade econômica de São Paulo:

"Excepto alguns dos filhos do Reino, que traficão em pequeno negocio de panos, e cedas, e outras miudezas pela mayor parte fazendas estrangeiras: Aquelles Tropeiros que negocião em animaes de Curitiba, e Viamão; alguns Paulistas que tem humas lemitadas lavras, em que faiscão o Ouro; tudo o mais vive mizeravelmente."

Não falta veracidade a esse quadro do depauperamento econômico de São Paulo. O Morgado de Mateus procura explicá-lo quando aponta, de um lado, para as poucas opções de sobrevivência - exercício de algum negócio ou exploração do trabalho escravo - e de outro, para a precariedade dessas opções, de vez que o comércio estava onerado pelas vendas a crédito e que os escravos, ao morrer, levavam consigo o capital que representavam. (69)

A fraqueza econômica de São Paulo gerou, pois, uma série de desajustes que se poderiam resolver pela agregação de pessoas economicamente deslocadas a outras que desfrutavam de posições mais sólidas.

3..$^{\circ}$ Ao nível institucional, a cidade não dispunha de uma rede de serviços sociais capacitada para responder às demandas de seus moradores,

por estarem as terras embaraçadas com letigios sobre limites, letigios, que alem de impedirem a cultura das terras e desviarem os lavradores de sua ocupação, os arruinão, e os poem em estado de suma pobreza..." (Carta do Governador para o Tribunal do Conselho Ultramarino, a 15/11/1798, Documentos Intesessantes, v. 29, p. 84).

"Ninguem trata de aproveitar os effeitos do Paiz, por cuja cauza se acha o Povo reduzido à mais lastimosa pobreza". (Carta do Governador ao Rei de Portugal, a 1/12/1767, Documentos Interessantes, v. 23 p. 253).

"Este hé hum paiz riquissimo; não falo só nas Minas, muitas Drogas, muito algodão; produz copiozamente, e no meyo desta abundancia não ha gente mais pobre, tudo geralmente está empenhado, e hé impossível que paguem, ainda aquelles de mayores creditos pouco tem, os seus cabedoces estão em papeis que nunca hão de recadar huma pequena divida porque os executem basta para os destruir; se morrem ficão os seus filhos a pedir)" (Carta do Governador ao General de Angola, a 3/11/1769, Documentos Interessantes, v. 19, p. 398).

(69) - "Todos os fundos dos cabedaes destas terra comsistem unicamente, ou no manejo do referido negocio, ou no labor da escravatura; o primeiro tem muitas falencias, porque passou a tanto excesso o abuzo de vender fiado nestes Paizes, que tudo consistem em dividas, em creditos e em conta, que não tem fim; e as dividas se perdem muitas e o dinheiro quase nunca se apura. Os escravos tãobem tem muitos inconvenientes, não só pelo que toca aos costumes, mas porque morrendo com ellas sepultarão juntamente todos os cabedaes: sobre estes fundamentos não são as couzas sólidas nem permanentes ... as mesmas villas, que já estão povoadas, vāo-se desfazendo ..." (Carta ao Conde de Oeyras, a 13/12/1766, Documentos Interessantes, v. 73, p. 88 ). 
e, ao mesmo tempo, o núcleo urbano como uma teia de relações sociais, não propiciava o aparecimento de associações voluntárias de tipo secundário. A participação social, assim, ficou grandemente marcada pelos vínculos primários, nos quais a parentela ou o círculo de vizinhança desempenhavam as funções que deveriam ser preenchidas por agremiações formais. Doentes, órfãos, velhos, enfermos, desvalidos de toda sorte, estavam à mercê de apoios aleatórios, proporcionados por particulares. Os grupos familiares passavam a atuar como desembocadouros de elementos inativos, fato que explica a proveniência de parte apreciável dos agregados. (70)

Os grupos marginalizados não constituíam, entretanto, um arcabouço isolado e com vida própria, mas eram produtos da sociedade no seu todo. Os sociólogos robustecem essa afirmação quando corrigem a teoria de que as "áreas marginais" teriam um conteúdo próprio, essencialmente diferente da cultura global. Pelo contrário, os contatos são intensos e as populações marginais articulam-se no conjunto da sociedade e tendem a funcionar com os demais setores, como componente de um mesmo todo social. (71) A marginalidade é vista como função do sistema, resultante da sociedade global que traz no seu seio um conjunto de contradições, cujas manifestações são múltiplas. Dentre estas manifestações, figura a descontinuidade que apresentam os grupos marginais no seu ajustamento ao complexo social total. Descontinuidade, não ruptura. (72)

A noção de descontinuidade, por outro lado, supera o abandono de instrumentos da análise nos termos de adaptação ao sistema, próprios da sociologia urbana tradicional (cujo eixo é o da integração), ineficazes para a compreensão dos grupos marginais quando vistos no concerto social. O raciocínio da integração aplicado aos elementos contraditórios encontrados nos setores marginais, levaria a uma simplificação perigosa da realidade. (7) Em outras palavras, os setores marginalizados seriam vistos da

(70) - Estudos sobre a marginalidade em São Paulo atual revelam profundas analogias com o passado. Afinal, os miseráveis de todas as épocas formam quadros bastantes parecidos. A respeito, conferir o trabalho de Lúcio Felix Frederico Kowarick: Crescimento econômico, urbanização e marginalidade social: algumas reflexões acerca da cidade de São Paulo (Contribuiçôes teóricas e metodológicas para formulação das diretrizes na ação da Sebes. São Paulo. Secretaria do Bem Estar Social, Assessoria Coordenadora de Planejamento Setorial, nov. 1971, Mimeo).

(71) - Martins, Carlos Estevam. "Integración social y mobilizacion politica de la clase baja urbana del Brasil", Revista Latino-Americana de Ciência Politica, FLACO, Chile, abril 1971, v. II, p. 1.

(72) - Op. cit., p. 36-42.

(73) - "La tradition de la sociologie urbaine est axée sur la problématique de l'intégration sociale comme il est normal si l'on se souvient de la demande qui en est à la base, étroitement liéé au paternalisme réformiste visant à effacer les méfaits de l'industrialisation capitaliste sur le plan de la consommation collective .... Les instruments d' analyse forgés par la sociologie urbaine sont alors, non seulement des instruments d'adaptation au système comme ils l'ont toujours été, mais parfaitement 
mesma forma que os integrados, perdendo o seu caráter de desajustamento à ordem social.

No estudo dos agregados, vistos como elementos fronteiriços entre grupos marginais e integrados, mais próximos aos primeiros do que aos segundos, é preciso considerar a proposição de que embora funcionassem como os demais setores da sociedade global, estavam sujeitos a mecanismos de descontinuidade que os desajustavam ao sistema. Com efeito, verifica-se que o viveiro por excelência de agregados situava-se na ralé numerosa e variada de São Paulo: vadios, mendigos, prostitutas, forros, bastardos.

Não parece temerário aventar-se a hipótese de que esses elementos poderiam ser reduzidos à agregação, por um processo seltivo - "um dos aspectos mais importantes da integração de homens em uma determinada sociedade ou seus grupos parciais". (74) A grande instabilidade dos agregados, no entanto, leva a crer que a integração de elementos marginais era bastante precária e quase sempre transitória.

O "peneiramento" de membros da ralé urbana implicava um sistema de valores (representação coletiva de uma experiência ou série de experiências positivas) cuja aceitação agregava os indivíduos à ordem social. Os que não passassem pela peneira permaneciam como "resíduos". Emílio Willems nota que contato e peneiramento sucessivo nem sempre significam que os indivíduos possam escolher os ajustamentos que lhes exige a sociedade e que determinam a sua integração. (75) Parece certo que os agregados nem sempre estavam na condição de optar. Os ajustamentos eramlhes, provavelmente, impostos como, de resto, aos integrantes do grupo que, dentro de uma terminologia empregada por E. Willems, poderia ser chamado de "resíduo social" (76): forros, bastardos, vadios, mendigos, prostitutas, crianças abandonadas. Digamos que alguns desses elementos, no passado, formassem certa massa potencial para a agregação. Nesse caso, o peneiramento fazia-se de um modo não organizado ou difuso, entre pessoas que se tornavam instrumentos ativos ou passivos da ação intra ou inter-

inopérants, du point de vue de la recherche, pour rendre compte de l'essentiel des problèmes posés par la pratique sociale. ... Le lieu théorique du concept de pouvoir est celui des rapports de classe. On entend par pouvoir la capacité d'une classe sociale de réaliser ses intéress objectifs spécifiques aux dépens des autres. Par intérêts objectifs on entend la prédominance des éléments structurels qui définissent, par leur combinaison, une classe, sur les autres éléments quent soi en contradition" (CASTELS, M. Propositions théoriques pour une recherche expérimentale sur les mouvements sociaux urbains. Communication au VIIe. Congrès Mondial de Sociologie, Varna, septembre 1970, Laboratoire de Sociologie Industrielle, p. 1-2 (mimeo).

(74) - Willems, E. "Problemas de uma Sociologia do peneiramento", Revista do Arquivo Municipal, v. 75, 1941, p. 5-6.

(75) - Op. cit., p. 7.

(76) - Op. cit., p. 8. 
grupal. Ainda, adotando a hipótese de peneiramento como explicação para o mecanismo da agregação, pode-se notar o caráter intersticial do processo, feito através de uma infiltração lenta e discreta. Ao mesmo tempo funcionava como um dos motores da mobilidade social, distribuindo e redistribuindo indivíduos em campos diversos de atividades.

A grande mobilidade horizontal que pode ser conhecida entre os agregados pelos recenseamentos do início do século XIX, indicaria a característica de distribuição e redistribuição de indivíduos por várias atividades. A pouca mobilidade vertical verificável estaria consoante com o peneramento de pessoas que ascendem por infiltração intersticial, processo "sumamente severo", segundo E. Willems. (77)

O recenseamento de 1804, ao registrar modificações ocorridas de um censo para outro, testemunha a movimentação nos núcleos familiais, ocasionada pelos agregados, agentes por excelência da movimentação horizontal da sociedade. Quando são feitas observações sobre as alterações ("casualidades") de um ano para outro, fica patente a instabilidade dos agregados nos fogos. Assim por exemplo: (78)

“... não confere por faltar agregada e crescer a mulher e filhos e outra agregada (Fogo 209); só falta o agregado José (Fogo 199); não confere por faltar o agregado Manoel (Fogo 258); não confere por ter vendido o Escravo Manoel e terem saído agregados (Fogo 215); não confere por crescer a agregada Anna (Fogo 482); nascerão. Benedito e os quatro agregados, Francisco, Rosa, Antonio, Odó (Fogo 3); não confere por crescer a agregada Thereza (Fogo 132); não confere por sairem os aggregados Custódia e José e se acharem outros Maria e Manoel (Fogo 163); e não confere por crescerem os agregados Justa, Esperança, Antonio e o escravo Pedro (Fogo 166); não confere por crescer ... as agregadas Justa, Massima e Maria (Fogo 190); só cresce o agregado Francisco (Fogo 200); não confere por haver diferença em escravos e sairem alguns caixeiros e ter outros (Fogo 320); não confere por ter saído o sobrinho João Baptista e crescer a filha Thereza e agregada Luíza (Fogo 119); faltam os agregados José e Jonoaria e crescer Joaquim e O escravo Paulo (Fogo 201); não confere por crescer os agregados Gertrudes da Cruz cunhada agregada, Thereza de Almeida agregada desta e Maria (Fogo 231); não confere por ter saído o agregado Francisco, nascer o crioulo Benedito (Fogo 294); não confere por crescer a

(77) - Cf. op. cit., p. 9, 24, 61 e 62.

(78) - Para facilidade de leitura, tendo-se em vista a citação extensa, julgada necessária, as abreviações estão resolvidas, assim como a redação simplificada. No original, desprezadas as variações, a forma mais comum é a seguinte: “... Obs.: comparada com a antecedente, n. 441, não confere $\mathrm{p} /$ ter saido a aggregada Felizarda e entrado Bernarda". Maços de População, 1804, 1." Companhia, Fogo n. 67. A.E. 
agregada Filipa (Fogo 304); não confere por ter falecido a escrava Maria, e ter comprado o escravo André e crescer a agregada Anna e a filha desta Maria (Fogo 341); cresce o agregado Antonio Felix (Fogo 380); não confere por faltar a agregada Anna (Fogo 408); não confere por ter falecido Rita e crescer a exposta Candida (Fogo 435); não confere por faltar a agregada Maria Joana (Fogo 445); nāo confere ... e crescer os agregados Elmenegilda e o filho da dita José e nascer Quitéria (Fogo 137); não confere por faltar o agregado Antonio da Costa Varella (Fogo ...); não confere por crescer o escravo Manoel e a agregada Joaquina (Fogo 118); não confere por faltar a agregada Apolônia (Fogo 113); não confere por crescer o agregado Elesbão (Fogo 110); não confere por crescer os Agregados Gertrudes, Esmenia e José (Fogo 106); não confere por ter saído a agregada Felizarda e entrado Bernarda (Fogo 67); não confere por faltar o agregado Francisco que saiu (Fogo 470); não confere por ter saído o agregado Lucas (Fogo 343); não confere por faltar agregada e acrescer os dois escravos (Fogo 250); Agregadas Cristina, Escolástica agregadas no ano (Fogo 28); Agregados Francisca, Innocencio Gonsalves soldado da Legião, Elesbão, Pascoa Maria acrescido neste ano (Fogo 30); não confere por estar ausente João e ter vindo Izabel e Matildes (Fogo 49); não confere por crescer a agregada Maria (Fogo 76); nāo confere por ter falecido D. Escolástica Francisca e a agregada Anna Maria que faleceu (Fogo 186); Foram acrescidas 2 agregadas (Fogo 15); não confere por crescer os agregados (Fogo 232); não confere por faltar os Agregados Joaquim Pereira e a mulher Ignácia Maria e os filhos desta Jacinto e Mannoela e faltarem os escravos deste Francisco, Antonio, João e Joaquim Antonio, e crescer a agregada D. Joanna e faltar o agregado Augusto Gonçalves (Fogo 241); não confere por sairem os agregados e entrar outro (Fogo 353); não confere por terem saídos os agregados (Fogo 382); não confere por crescer o agregado Luciano e o escravo Francisco que comprou (Fogo 390); Maria Thomásia agregada ... entrou no ano (Fogo 41); Maria dos Prazeres agregada no ano; não confere por faltar Gertrudes, Vicencia e de novo Maria, Casa nova (Fogo 45); não confere por faltarem os agregados Pedro e Alcino (Fogo 157); não confere por crescer a agregada Gertrudes (Fogo 125); não confere por ter saído a filha Maria e a neta Ignacia Maria filha desta Anna (Fogo 121); não confere por crescer a agregada Francisca (Fogo 85); não confere porque faltou os agregados Maria e Manoel e crescer Demetildes e Luiz (Fogo 58); não confere por faltar o Escravo Matheus e Benedita que se vendeu e crescer os Agregados Maria e Margarida e Manoela (Fogo 240); não confere por faltarem dois agregados e três escravos (Fogo 381); não confere por faltar a agregada que estava e crescer outra (Fogo 383); não confere por faltar agregada Gertrudẹs que se casou (Fogo 386); não confere por faltar o agregado Theodosio 
(Fogo 410); não confere por faltar a mãe Grácia e crescer a filha Francisca e a agregada Gertrudes (Fogo 464); não confere por faltarem os agregados, hum escravo e crescer a Irmã Escolástica (Fogo 387); não confere por ter morrido o agregado Elautério (Fogo 259); não confere por terem saído os agregados (Fogo 208); não confere ... acrescer Ursula escrava de Sua Alteza da Fazenda de S. Anna e sair o agregado Joaquim (Fogo 152); Falta pela lista antecedente o agregado José que senão sabe o rumo que tomou (Fogo 4)". (79)

Estes casos. que monotonamente se repetem, são expressivos pela quantidade e por ilustrarem a intensa rotatividade dos agregados. A secura documental não permite, infelizmente, que se apreendam as circunstâncias que acompanhavam o "saimento" ou o "crescimento" de pessoas. Não obstante, patenteia-se uma certa vocação de fogos para receptáculos de agregados. Algumas notações são expressivas, como no fogo 163, que perdeu os agregados Custódia e José, mas achou outros, Maria e Manoel (80) A procura de agregados, o seu "achatamento", demonstra que eles eram necessários à economia familial, funcionando talvez como "Ersatz" de escravos. A incorporação ou a perda de agregados, em grupos de duas ou mais pessoas, muito frequientes, reforçam a teoria do uso de uma força de trabalho criada pelas peculiaridades do mundo pioneiro, intermédia do trabalhador livre e do escravo.

Os meios não integrados ou mal integrados à sociedade paulistana, espécie de submundo colonial, funcionavam como viveiros de agregados. Daí a necessidade de um breve estudo a respeito.

De início uma distinção se impõe: existiam setores ajustados aos padrões sociais, embora não integrados, tais como, índios, bastardos, forros, crianças órfãs ou expostas, e outros, constituídos por indivíduos que embora não fossem criminosos, no sentido estrito, transgrediam normas e valores sociais, de modo a preocupar a coletividade. Estes últimos eram os vadios, mendigos e prostitutas, vistos como perigo em potencial, mazela que deveria ser eliminada, controlada, oculta. (81) Por numerosos meios a sociedade procurou dominar esta massa flutuante, parte inarredável da paisagem social e que revelava a sua própria vulnerabilidade. Um desses meios era a agregação. Com efeito, o confronto entre situações cotidianas

(79) - Maços de População da Capital - 1. Companhia de Ordenanças, 1804. Arquivo do Estado. Ms.

(80) - Seriam os mesmos Maria e Manoel que faltaram ao fogo 58? O vácuo deixado foi preenchido por duas agregadas Dometildes e Luzia ou, talvez a pressão exercida pelas recém-chegadas provocou a expulsāo das anteriores. (Cf. citação supra).

(81) - Nem sempre é possível estabelecer a oposição entre uns e outros. A família, por vezes, vizinhava com a prostituição, no caso dos concubinatos; os forros resvalavam para a vadiagem; os doentes, para a mendicidade. 
que engendravam e suscitavam a existência de grupos desajustados à ordem social e a presença dos agregados, revela a existência de canais comunicantes entre uns e outros. Fazem-se, pois, necessárias algumas considerações sobre os setores "marginais" de São Paulo, de vez que apresentavam situações que poderiam conduzir à agregação, através de processos seletivos, organizados pelo meio social.

\section{A - INDIOS ALDEADOS (82)}

Nas áreas periféricas de São Paulo, os aldeamentos indígenas do século XVIII constituíram viveiros significativos, aos quais os povoadores poderiam recorrer para suprir necessidades de mão-de-obra. Nesse sentido, a atuação dos paulistas sujeitou-se à legislação concernente aos índios, adaptando esta aos seus interesses. A partir do Alvará de 8 de maio de 1758, a administração de ameríndios exercida por particulares foi extinta, subsistindo apenas a tutela exercida pelo Estado sobre os núcleos que se formaram no decorrer da história da colonização dos Campos de Piratininga. (83) Anteriormente a essa medida, as autoridades sancionaram a escravidão disfarçada do índio, obrigando-o a continuar a servir o europeu, apesar das sucessivas medidas legais que o situavam juridicamente como homem livre. (84) A administração foi a forma encontrada pela Coroa de coibir abusos dos colonos, institucionalizando o uso dos índios, de modo a salvaguardar alguns de seus direitos, considerados legítimos.

Uma provisão do governador da Capitania, datada de 25/1/1694, declarara que os indígenas deveriam ser considerados livres e como tais tratados pelos moradores, os quais se comprometiam a vesti-los e a doutriná-los, mantendo-os sob administração. Diante de conflitos criados em torno da nova instituição, foi baixada a Carta Régia de 19 de fevereiro de 1696, concedendo a administração dos índios aos moradores de São Paulo que os haviam trazido do sertão e a seus descendentes ou àqueles que os mantivessem em serviço. Entretanto, estipulava-se que os índios deveriam viver em aldeamentos, dos quais só sairiam em ocasiões determinadas e por prazos fixos. (85) Pasquale Petrone esclarece que embora essas

(82) - A respeito, fornece subsídios preciosos o trabalho de Petrone, Pasquale. Os aldeamentos paulistas e sua função na valorização da região paulistana. Estudo de Geografia Histórica, já citado.

(83) - Petrone, Pasquale, op. cit., p. 57.

(84) - Cf. op. cit., p. 59 e 63.

(85) - "... os indigenas deveriam trabalhar uma semana para si e outra para seus administradores, sendo, neste último caso, pagos pelo seu trabalho; indo ao sertão, os moradores poderiam levar para seu serviço até a metade dos indigenas dos aldeamentos, a ausência não podendo durar mais de quatro meses ...; as índias só poderiam sair em dois casos, sempre em companhia de familiares, em atividades que lhes fossem próprias especialmente como amas de leite; no caso de 
medidas permanecessem no papel, estabeleceram uma intima relação entre a administração do gentio e os aldeamentos existentes e, por outro lado, fortaleceram os moradores, os quais continuaram a manter administrados em suas casas e puderam, ao mesmo tempo, servir-se dos aldeamentos tutelados pela Câmara de São Paulo.

Os interesses em jogo, representados pelos colonos e pelos religiosos, traduziram-se em atos que assim podem ser resumidos:

- Bando de Rodrigo César de Menezes, de 17 de março de 1725, estabelecendo medidas coercitivas contra índios, índias e bastardos que se iam livrando da administração dos moradores.

- Carta Régia de 10 de julho de 1726, vindo de encontro aos bandos de Rodrigo César de Menezes e dos moradores e que proibia aos indígenas de se retirarem das casas de seus administradores.

- Regimento para instituição da administração, resolvido em reunião com a participação dos beneditinos, carmelitas, franciscanos e outros, e que representou "um elemento de passagem para uma fase em que iriam se harmonizar os interesses em jogo. A tendência seria a de permitir que os moradores mantivessem administrados, porém sob controle do governo da Capitania. $\mathrm{Na}$ prática os moradores passariam a ser como que depositários de uma força de trabalho que, a qualquer momento, conforme as conveniências do 'serviço de Sua Magestade', poderia ser requisitada pelo governo da Capitania". (86)

- Bando do Conde de Sarzedas, de 19/3/1733, ordenando a todos que devolvessem os índios aos seus aldeamentos, por constar-lhe que esses estavam com poucos habitantes. (87)

Esta última medida foi seguida de uma tempestade de requerimentos e de protesto dos moradores, que testemunham a evolução do problema do uso do aborígene e as condições em que se verificava a administração.

Apoiando-se em exemplos cuidadosamente citados, Pasquale Petrone alinha inferência de grande importância para o entendimento da situação do índio na sociedade paulistana. Assim, observa que na prática, o administrado era um bem que poderia ser transmitido por herança. Os documentos deixam perceber, embora o fato não seja sempre explicitado,

casamentos com escravos, estes ficariam livres, indo residir nos aldeamentos; na ausência de descendentes dos administradores falecidos, os aldeamentos ficariam pertencendo à Coroa". (Op. cit., p. 48-49).

(86) - Op. cit., p. 49 e 52.

(87) - Op. cit., p. 52. 
que o administrado continuava em situação de ser vendido. (88) Estas duas características aproximavam inelutavelmeente o índio da categoria servil.

O contingente demográfico dos aldeamentos era altamente instável, uma vez que os índios procuraram fugir do impasse criado pelo Governo da Capitania que os prendia a situações indesejáveis de vida, quer nos aldeamentos quer na administração. E, para reforçar a instabilidade da condição livre legalmente assegurada ao índio, permanecia o fato de os administrados, por vezes em grande número, espalharem-se pelas casas de moradores de várias categorias sociais. (89) É o que se verifica pelo Levantamento de pessoas, seus escravos e suas profissões (1720-1732), onde pode ser vista a presença assídua de administrados em casas de moradores, juntamente com "servos", escravos e peças. (90)

Como forma importante da ocupação do planalto, os aldeamentos são contemporâneos aos primeiros estabelecimentos de europeus, "serra acima". Na segunda metade do século XVIII, funcionando como reservas dos "motores animados" aos quais se refere Pasquale Petrone, (91) os aldeamentos serviram de poderoso escoadouro para elementos considerados socialmente indesejáveis, fato que explica a grande heterogeneidade étnica de sua população. Como exemplo, em 19 de julho de 1766, foi ordenado ao diretor de São Miguel que recolhesse todos os indígenas dispersos, mas, também, os forros, vadios e toda gente inútil que achasse "desranchada". Esse processo continuou no último quartel do século XVIII, intensificando-se no início do XIX. Os contingentes ameríndios foram-se descaracterizando etnicamente, tornando-se caboclos, "até adquirirem as características mais típicas de uma população caipira que, ainda na atualidade marca

(88) - No inventário de Mateus Nunes de Siqueira (1732, Paranapanema e Cubatão) pode ser lido: "... uma carijó do gentio Caxipona, por nome Perpétua que valerá conforme foi avaliada por dois avaliadores quarenta oitavas de ouro" (Doc. não publicado, Livro de registro de testamentos, fls. 1.AE. Ms).

(89) - Petrone, Pasquale. Op. cit., p. 53-56.

(90) - E provável que "servo" fosse termo aplicado aos índios, do mesmo modo que peças; entretanto, há um certo cuidado em discriminar os indigenas sujeitos à administração. (Documento encontrado no Arquivo Municipal de São Paulo. Ms).

(91) - O autor arrola doze núcleos: Pinheiros, São Miguel, Barueri, Carapicuíba, Guarulhos, Embu, Escada, Itaquaquecetuba, Itapecerica, São José, Peruíbe e Queluz. No planalto, sobressaíam os aldeamentos situados na área de influência de São Paulo: Pinheiros, São Miguel, Barueri, Embu, Guarulhos, Itapecerica e Carapicuíba. Mais distantes ficavam os aldeamentos de Escada, Itaquaquecetuba e São José. Quanto à origem, distingue os aldeamentos formados por indigenas que resolveram viver em comum no território que lhes fora conquistado pelos brancos ou então por índios forros ou evadidos da administração de particulares. No primeiro caso estariam inscritos os aldeamentos de Pinheiros e São Miguel; no segundo, os aldeamentos que passaram aos jesuítas por doação, tais como do Embu, Escada, Carapicuíba, Queluz. Cf. op. cit., p. 71, 81 e 82. 
com sua presença alguns ângulos dos arredores de São Paulo, especialmente em torno dos antigos aldeamentos." (92)

Este fato, aliado à decadência das aldeias, foi detectado por viajantes do século XIX, que deram descrições bastante sugestivas de índios, resíduos de diversas tribos, vivendo misturados com negros e mulatos, meio incultos, espalhados entre os colonos. Marcados pela ociosidade, depredavam ocasionalmente as roças e o gado de seus vizinhos, no dizer de Spix e Martius. Estes mesmos autores registraram a queixa de um padre, que dirigia a Aldeia da Escada, sobre a restrição constante de seu raio de ação, em consequiência da ordem régia que concedera aos silvícolas os mesmos direitos que tinham os outros habitantes livres. Investidos desse direito, os moradores das aldeias se dispersavam, indo para o interior das matas. Quando da visita dos viajantes alemães, a Missão contava com apenas sessenta paroquianos, cujas figuras não os impressionaram favoravelmente:

“Não são restos de uma só nação, porém mistura de diversas que existiam nesta região, antes dos portugueses. $O$ seu semblante nada tem de agradável. O traço característico da raça, imbecilidade sonsa e taciturna, que se traduz sobretudo pelo olhar soturno e pelos modos acanhados dos indígenas americanos, ainda mais se acentua aos primeiros passos, quando começam a refletir sob o constrangimento da civilização, que lhes é ainda totalmente estranha, e ao contato com negros, mestiços e portugueses, chegando até ao ponto trágico de descontentamento surdo e perversidades. O modo como os tratam muitos dos atuais fazendeiros também contribui para tal decadência moral e física." (93)

A legislação ineficaz da Metrópole aliou-se, evidentemente, à erosão demográfica provocada pelos colonos, ocasionando a decadência dos aldeamentos. Das "razias" efetuadas pelos moradores em busca de mão-de-obra gratuita ou quase, dão conta numerosos documentos. Sobressaem os róis dos habitantes das aldeias, encomendados pelas autoridades do século XVIII e que se referem repetitivamente a indígenas desviados por colonos:

“... hua filha cazada asistente em caza do defunto Salvador de Oliveira; (94) Lista dos que andã pelas minas ... Todos estes asima nomeados se não sabe em que minas estão nem caza doande asistão,

(92) - Op. cit., p. 89-90.

(93) - Spix e Martius. Viagem pelo Brasil. 1817-1820, trad. de Lúcia Furquim Lahmayer, 2. ed. São Paulo, Ed. Melhoramentos, s.d., v. I, p. 124, 136-137.

(94) - Lista da gente q' de prezente se acha nesta Aldea de N. S. do Mon Serrat e dos Pinheiros. Boletim do Departamento de Arquivo do Estado de São Paúlo. São Paulo, Tip. do Globo, 1945, v. V, maço 2. 1721-1904. Aldeamento de Indios, p. 64 (1722).

(95) - Id., ibid., p. 67. 
e já há bastantes annos que por lá andão (95); Lista dos que andão em varias Vilas. Na praya da Conceição, em caza de Ambrozia Cardozo, assiste o índio Domingos, filho de João Pinheiros; Na Vila de Sorocaba, em caza de Antonio Antunes a india Catherina, cazada com hư seu mulato". (96)

Na Aldeia de N. S. da Escada, foram arrolados sessenta e dois índios, dos quais só se encontravam presentes trinta e um. Dos ausentes, nove "sem contar as crias", estavam nas minas; quatro, na Aldeia de Mangaratiba, quatro "sem contar as crias", na Aldeia de São Miguel; um na Aldeia de Maroeri; duas bastardas pardas, em casa de Anna Esteves, em Sorocaba; ainda em Sorocaba, dois bastardos; em Jacareí, na casa de Anna Pimenta, um índio e uma índia; em poder de Salvador de Madureira, um índio que foi levado por um soldado da praça da Vila de Santos. (97)

$E$ certo que dentre a gama de fatores que influíram para o ocaso dos aldeamentos, um sobressai: eles deixaram de interessar à Administração, transformando-se em valhacoutos de vadios e desordeiros, e como tais não teriam condições para se desenvolverem. (98)

Ademais, os exemplos deixam inferir que a agregação funcionou como fator de estiolamento das aldeias, à medida em que desviava para serviços de particulares os seus moradores, os quais passavam a "assistir" em casas que adquiriam, dessa forma, alguns de seus agregados.

\section{B - BASTARDOS E FORROS}

Geralmente chamados de bastardos e forros pela documentação, evadidos da condição de administrados ou de escravos, havia elementos socialmente inferiorizados, que iam engrossar o submundo dos grupos dos mal ajustados ou inteiramente desajustados aos padrões sociais dominantes.

(96) - Id., ibid., p. 67.

(97) - "Indios prezentes e abizentes da Aldeia de N. S. da Escada termo desta Villa de Santa Anna das Cruzes de Mogy", Boletim do Departamento do Arquivo do Estado de São Paulo, 1943, v. IV, maço 1. 1722-1822, p. 30-31.

(98) - A extinção das Aldeias indígenas faz parte do contexto global da ocupação do solo pela colonização européia, que como observa Egon Schaden, significou uma árdua e tenaz "competição ecológica entre os primitivos donos do território $e$ as levas sucessivas de povoadores e imigrantes, que, no decorrer de três séculos e meio, vieram ocupar légua por légua em ritmo crescente, o chão indígena - ora cruzando-se como o silvícola, ora combatendo-o pelas armas, ora subtraindoThe simplesmente, pelo fato da ocupação, as mais elementares condições de existência. E na segunda década deste século os naturais da terra, na medida em que não foram absorvidos biologicamente pelos ádvenas, haviam praticamente deixado de existir, para ceder o lugar a estes". ("Os primitivos habitantes do território paulista”, Revista de História. São Paulo, 18, 1954, p. 386. 
Esses elementos forneceram agregados à população de S. Paulo, através de certos mecanismos seletores.

Os bastardos aparecem desde os primeiros momentos do estabelecimento de portugueses no planalto, como parte representativa - e por vezes inquietante - dos moradores.

Desde os filhos de João Ramalho, o vocábulo "bastardo" afastou-se do conteúdo que carregava em Portugal, onde designava filhos espúrios, havidos fora do matrimônio, para se aproximar da significação mais restrita à etnia, de "modificado, degenerado". (99) Perdeu a acepção puramente jurídica e passou a designar o mestiço de índia e branco: o mameluco. Forma sui generis brasileira e mais particularmente paulista, não registrada pelos dicionários. (100)

Littré, por exemplo, não registra o emprego de bastardo para híbridos humanos, embora o faça para animais e coisas. Em seu dicionário, bastardo é o nascido fora do casamento, havendo o simples bastardo, aquele nascido de pessoas livres, por oposição ao bastardo adulterino. Como segunda acepção consta a de degenerado da espécie à qual pertence: oliveira bastarda, maçã bastarda. Em terceiro lugar, observa que bastardo junta-se a muitos substantivos e indica que a coisa da qual se trata sofrem qualquer modificação que a mudou e a diminuiu. Recusa, ainda, a etimologia que liga a palavra bâtard ao produto de bât, indicando desprezo, no caso, com a terminação ard frequiente em francês e derivada do alemão art, espécie, sorte, maneira de ser. Diz textualmente: "On trouve aussi, par une corruption née de l'ignorance du sens et par une fausse étymologie, fille de bas, bâtard, venir de bas, être bâtard". (101) Essa falsa etimologia, porém, corresponderia, no caso paulista, a uma verdade social. De fato, não restam dúvidas de que a palavra bastardo estava associada aos membros mais baixos da sociedade, à ralé, à gente vil, contra a qual deveriam ser tomadas precauções, a bem da ordem social. Os critérios étnicos que presidiam a essa desvalorização estão evidentes nos testemunhos da época: "Por este nosso edital indo primeiro por nos asignado e na forma delle mandamos que nenhum negro ou bastardo (sic) e mulato ou pessoa vil de qualquer calidade que seja joquem jogo algum no Aganhabau". (102) Esta restrição não se limitava aos escravos, mas também aos forros, estes, livres da pena de cinquienta açoites, dados no pelourinho aos escravos, mas obrigados ao pagamento de seis mil réis e a trinta dias de cadeia. As tardo.

(99) - Figueiredo, Cândido de. Dicionário da Língua Portuguesa, verbete bas-

(100) - Nos limites em que se desenvolveu esta pesquisa, evidentemente.

(101) - Dictionnaire de la langue française, tome 1, verbete bâtard.

(102) - Registro de hum edital dos offeciais da Camara sobre não çe jogar no Anhanbau. Ordens régias (1740), Revista do Arquivo Municipal de São Paulo, v. CXIX, p. 87. 
razões alegadas são, primeiro, de ordem econômica: “... por nos constar que actualmente estão jogando faltando ao servissos a seus senhores". (103); segundo, de segurança social: "... e fazerem varios furtos para tal efeito e outrosy com bulhas e pendencias cauzando do refrido jogo de que pode resultar morte". (104)

São raros os documentos em que a palavra bastardo aparece isolada de menções a outros grupos pertencentes à escória social. (105) De modo geral, o rito é mais ou menos o mesmo. Por exemplo, em 1722, o ouvidorgeral da Comarca de São Paulo expôs opinião de que a sentença de morte era mais necessária na terra paulista do que em outras regióes, por haver maior número de culpados. Assim, propôs que fosse permitido a ele, ao governador e ao juiz-de-fora de Santos, condenar à morte os escravos, índios, mulatos e bastardos, ainda que forros. (106) A situação parece não se ter definido claramente, uma vez que em 1769 o Conde de Valadares remeteu a D. Luiz Antônio de Souza determinações para que fossem condenados à última pena os delinquientes bastardos, carijós mulatos e negros. (107)

Ao mesmo tempo, sujeitavam-se os bastardos a terem sua liberdade limitada, como acontecia às pessoas cuja pobreza combinava-se à caracterização étnica dos escravos. Em mesmo bando em que Rodrigo César de Menezes atende aos reclamos dos povoadores, obrigando os índios a servirem de mão-de-obra praticamente gratuita, os bastardos também foram incluídos. (108)

(103) - Id., ibid.

(104) - Id., ibid.

(105) - Os critérios para a identificação dessa "escória", não se associavam apenas à cor; o exercício de profissōes humildes ou a ausência de ocupações também tinham peso, como se nota neste documento: “. . chamado também, para tal deligencia, taverneiros, mullatos, e bartardos, e indios, do gentio da Terra, e cayxeiros, e alguns rapazes que todos uniformemente vinham a ser o mesmo, e ainda alguns forausteiros, que nenhum conheçimento tinhão do dito sendicato..." in: "Registo das Suspeissoins postas ao Sindicante Antonio de Souza de Abreu Grade estando tirando e rezidencie do sendicato Manoel de Mello Godinho Mansso" (Documento n. 127, Revista do Arquivo Municipal, v. XIX, 1936, p. 112).

(106) - Consulta do Conselho Ultramarino sobre a carta do ouvidor-geral da comarca de S.P., de 10/10/1722, expondo divergências que há entre o regimento que usa no seu cargo e o do Rio de Janeiro (Documento n. 341, do Arquivo Histórico Ultramarino, súmula ms. existente no Centro de apoio à pesquisa histórica/ USP).

(107) - Carta do Conde de Valladares, escrita de Vila Rica, em 5/5/1769 a D. Luiz Antônio de Souza, Documentos Interessantes, v. XIV, p. 245.

(108) - “... por Se me Reprezentar por parte das Camaras desta cidade e de algumas villas desta Capitania, o pRejuizo que Se Seguia dos ditos Bastardos e bastardas estarem na Sua Liberdade e Ser conveniente atalharsse Semelhante danno; Ordeno e mando que todos os indios e indias Bastardos e Bastardas que Se acharem 
A Câmara não manifestava escrúpulos em se aproveitar do trabalho de pessoas juridicamente livres, obrigando-as a trabalho não remunerado, como o do conserto do caminho de Santana, que ficou a cargo dos índios administrados e dos "carijós e bastardos que vivem sobre sy". (109)

Os bastardos compuseram uma camada social suficientemente definida para dela os contemporâneos demonstrarem consciência. Em 1765, o censo registrou quatrocentos e quarenta e um bastardos na população da cidade de São Paulo. O bairro do Pari era habitado por "quase todos, gentes bastarda", (110) revelando um certo arranjo racial na geografia urbana, próprio de uma sociedade preconceituosa, fato, aliás, inegável pela documentação.

Embora a filiação ilegítima permaneça implícita no termo "bastardo", mesmo porque a origem do tipo social prendia-se à procriação espúria, tão frequiente entre os paulistas, os documentos coloniais revelam certo cuidado em distinguir a prole extra-conjugal do grupo propriamente dito. A respeito, a provisão régia de 17/11/1713 é elucidativa: na lista das pessoas consideradas culpadas pela morte do desembargador sindicante Antônio da Cunha Souto Mayor, D. João V menciona Guilherme Pompeu, filho do Padre Guilherme Pompeu; Romão Forquim, genro do dito Padre e "os bastardos e correios (sic) que consta serem do Padre Guilherme Pompeu". (111) A expressão "bastardos" não inculca a afirmação de que os indivíduos a que se aplicava fossem filhos do Padre Pompeu, uma vez que era qualificativo de mestiço, usado corretamente pela linguagem da época. (112)

Evidentemente, podiam existir coincidências entre a filiação ilegítima e o tipo étnico, hipótese bastante plausivel dentro do quadro social da época.

A verdade é que os bastardos, mestiços ou filhos espúrios, estavam duplamente expostos à agregação: tanto pela situação indefinida em que

nesta Capnia. em Sưa liberdade venhão a minha pResença em termo de tres dias ..." (Registo de hum Bando que o Exmo. Snr. Governador e Cappam. Gnal mandou Lanssar para que dentro de tres dias todo o Bastardo e Bastardas indias e mulatas que tivessem suas alforrias as apResentassem na Sua Prezença”. Doc. n. 175 de 21/4/1725, Revista do Arquivo Municipal, v. XXIV, p. 241).

(109) - Registro de quatro mandados do offeciais da Camara pa. as facturas dos caminhos na forma que nelles se declarão. (Doc. n. 472 de 26/6/1740), Revista do Arquivo Municipal, p. 472).

(110) - Citado por Florence, Amador. Curiosidades do censo..., p. 140-141.

(111) - Correios resultou de um provável erro de copista, uma vez que os documentos da época costumam registrar "bastardos e carijós". Cf. Taunay, Afonso d'E. "O mais velho documentário paulista de escrituração mercantil e bancária. Anais do Museu Paulista, v. XV, p. 35.

(112) - Id., ibid. 
se encontravam, quanto pelos eventuais laços de sangue, reconhecidos ou não, que os ligassem aos chefes dos fogos.

O estudo dos forros em São Paulo mostra que o termo foi usado, muitas vezes, como ardil destinado a iludir a legislação que garantia a liberdade dos índios. Peças forras ou forros, os aborígenes poderiam ser escravizados, partilhados, vendidos, ao abrigo de uma terminologia falaz.

Entretanto, de mistura com estes "falsos" forros, existiam indivíduos que de fato haviam conseguido a sua alforria, de acordo com costume que se consagrara na prática social. Às vezes, por mera conveniência, os escravos velhos ou doentes eram libertados (113); outras vezes, como recompensa pelos bons serviços prestados ou devido à afeição que os unia a seus donos.

A respeito desta última prática, Saint-Hilaire pondera que seus efeitos eram péssimos: o liberto, quando velho, não teria como se preservar da indigência, e, se jovem, por causa da preguiça ou da falta de inteligência, não tendo aprendido nenhum ofício, ele se tornaria vagabundo ou mesmo ladrão e assassino. A maioria dos negros condenados no Rio de Janeiro era constituída de libertos.

Esta opinião é confirmada relativamente a São Paulo:

\begin{abstract}
"Os negros que os senhores libertam são, geralmente, aqueles cujos prolongados serviços querem recompensar; e, as mais das vezes, os velhos que nada mais produzem; as alforrias dos muito jovens, são excepcionais. Os primeiros não podem pensar em casar-se; os segundos dificilmente encontram individuos de sua casta aos quais se possam unir. Além disso, não tendo sido preparados para a liberdade, por meio da necessria instrução, preferem a vida regrada e familiar, a vida dos camaradas, a libertinagem, ou, mesmo, o crime." (115)
\end{abstract}

As observações feitas acima previnem a respeito da falta de opções dos forros; teriam que ocupar áreas periféricas da sociedade ou recair num cativeiro disfarçado: a agregação.

O número de forros, como tais definidos nos recenseamentos coloniais, não era grande. Provavelmente porque boa parte sofria a influência da agregação e acabava, em consequiência, assim rotulada. Nos bairros do Pari e Pinheiros, em 1777, em 4.338 indivíduos, incluíam-se 46 forros e

(113) - "Sinto dizer que tais escravos, chegando à velhice, quando já se tornavam imprestáveis para o serviço, são alforriados, e, assim, entregues ao desamparo". (Spix e Martius, Viagem pelo Brasil, Tomo II, p. 172).

(114) - Viagem pelo distrito dos diamantes e litoral do Brasil, trad. de Leonam de Azeredo Penna, Belo Horizonte, Ed. Itatiaia/São Paulo, EDUSP, 1974, p. 122.

(115) - Viagem à Província de São Paulo, p. 80. 
13 libertos; entre os agregados, 254 mulheres e 135 homens, sem incluir os 58 expostos de ambos os sexos. (116) Este exemplo fornece uma medida aproximativa da presença de forros na população. Poucos viviam em fogos independentes; na generalidade, agregavam-se a casas estranhas, provavelmente de seus ex-senhores. No campo, segundo Rugendas, uma vez libertados, os negros instalavam-se nas imediações da fazenda em que trabalhavam, cultivando uma porção pequena de terra pertencente a seus antigos senhores, por um arrendamento módico, ou a título de gratuidade; também trabalhavam por dia, como camaradas. (117)

Com a alforria, vinha o sobrenome, geralmente adotado de seus senhores. (118) Também sobrenomes hagiológicos, de Jesus, da Conceição, não eram raros.

A liberdade conseguida pelos forros era positivamente limitada. Quando não decaiam na marginalidade pura e simples - como Gertrudes, forra andante, que levou a batizar seu filho Manoel, de pai incógnito - (119) acabava por se avizinhar de novo da condição servil, mediante expedientes vários.

E o caso da libertação de uma escrava de Archangela Ortis de Camargo, por testamento de $15 / 6 / 1775$, o qual demonstra a precariedade da condição de livre da contemplada pela medida:

"Declaro que é minha vontade que a escrava Marianna fique na sua Liberdade e se podera acostar para viver em qualquer companhia de meos filhos ou filhas conforme quizer lhe parecer como tanto que viva sempre obrigada ao lavar e caridade e zello de alguns de meos filhos ou filhas."

Não menos limitada foi a alforria do crioulo Antonio, uma vez que a sua dona impôs-lhe a obrigação de servir a seu marido, enquanto este vivesse, e após a sua morte à Nossa Senhora das Dores da Cidade, à qual pagaria sete patacas cada ano, retiradas de seu serviço livre. (121)

(116) - Maços de população da Capital. AE. Ms.

(117) - Rugendas, João Maurício. Viagem pitoresca através do Brasil, p. 59.

(118) - Santa'Anna, Nuto - Thebas, Revista do Arquivo Municipal, v. XVI,

(119) - Registros de batismos. Paróquia da Sé, Livro 5, armário 2, prateleira 2 , n. 40 , p. 16 .

(120 - Registro de Testamento de Archangela Ortis de Camargo, São Paulo, 15/6/1775, Ms, Livro 3, Cx. 455, fls. 94 v. (Arquivo do Estado).

(121) - Testamentos de D. Anna Maria de Jesus, São Paulo, 23/2/1786, Ms., Livro 3, Cx. 455, fls. 106 v. (Arquivo do Estado). 
As alforrias isentas de qualquer tipo de obrigação parecem ter sido raras e geradoras de desajustamentos sociais. (122) A consciência dos perigos da desproteção a que ficariam expostos os escravos que queriam premiar, associada talvez a uma intenção consciente ou inconsciente de reaproveitamento da força de trabalho que desta forma se perdia, levava os moradores a impor condições para a alforria, as quais implicavam uma forma de agregação. E crível que os próprios forros, sabendo-se destinados à marginalização no mundo dos homens livres, preferissem permanecer nas casas de seus antigos donos ou a elas retornar, transmudados então em "agregados". (123) Esta mudança de situação está bem clara em alguns documentos, como este:

"Diz Joaquim José de Almeyda, pardo forro, q' vivendo agregado à D. Maria de Almeyda, da V.a de Sorocaba, de q. ${ }^{m}$ foi escravo, e obteve a sua liberd.e ..." (124)

Em algumas casas, viviam vários forros em situação de agregados. É o que consta do fogo de Jozé de Oliveira Falcão, morador em Sorocaba, onde viviam, com mais seis escravos, dezessete agregados forros, cujas idades variavam de cinco meses a oitenta anos. (125) A maior força de trabalho era constituída, assim, não por escravos mas sim por agregados. Estes seriam ex-escravos da casa ou pessoas estranhas recolhidas por diferentes motivos, dentre os quais poderia estar mesmo a caridade cristã? Pelo menos em relação aos indivíduos de oitenta anos esta última hipótese parece ser a mais plausível.

(122) - "... os mulatos e pretos são de ordinário cegos, aleijados, velhos e estropeados; a mayor parte destes proveem da mal entendida charidade de huns e da escandaloza deshumanidade de outros; chamo charidade mal entendida a daqueles senhores e senhoras que deixão por sua morte fôrros escravos e escravas sem officio, sem legado e sem arrimo (Vilhena, Luiz dos Santos. Recopilação de notícias soteropolitanas e brasilicas, contidas em $X X$ Cartas. Ano de 1802. Bahia, Imprensa Oficial do Estado, 1921, p. 134).

(123) - Nos testamentos, as formas de alforria implicam, ipso facto, na agregação: "Deixo hum escravo por nome Francisco, forro e este estara em companhia de meus herdeiros com quem elle quizer..." (Testamento do Capitäo Francisco Pereira Mendes. São Paulo, 28/4/1782, Ms., Cx. n. 455, Livro 3, fls, 72 v., Arquivo do Estado). "Declaro que he minha ultima e derradeira vontade deixar Liberta a escrava por nome Barbara e que fique izenta de toda a escravidāo com obrigaçāo de enquanto vivo meo filho Gregorio fazerlhe companhia acostados a meo filho Raphael e o valor da dita Escrava sahira da minha terça..." (Testamento de Maria de Almeida Lopes, Jundiaí, 26/2/1786, Ms., Cx. 455, Livro 3, fls. 125, Arquivo do Estado)

(124) - Pedido da relaxação de prisão. São Paulo, 1784, Ms., n. de ordem 339; n. de Cx. 92, Arquivo do Estado).

(125) - Maço de população de Sorocaba, 1780, Ms., n. de ordem 168, n. Cx. 168, fogo n. 154, Arquivo do Estado. 
Por outro lado, o casamento com escravos tornava os forros agregados necessários, como podemos verificar nos recenseamentos coloniais e em testemunhos de natureza várias. Algumas petições dirigidas ao capitão-general de São Paulo falam que os casamentos juridicamente híbridos escravos e livres - provocavam situações conflitantes e provavelmente insolúveis fora da fórmula da agregação. (126)

De tal sorte, a agregação constituiu uma espécie de zona de segurança, na qual se obrigavam os forros, pressionados por medidas de contenção expressas nas determinações de seus "livradores", ou decorrentes das condições sociais adversas, que impediam maior integração dos elementos egressos do sistema servil.

\section{C - CRIANÇAS ILEGITIMAS, EXPOSTAS E ÓRFÃS}

Em estudo sobre as taxas de ilegitimidade na cidade de São Paulo, entre 1750 e 1850, Maria Luíza Marcílio apurou que para cada cem crianças nascidas vivas, quarenta eram ilegítimas, o que demonstra que a procriação efetuada fora dos parâmetros socialmente aceitos era prática frequiente. (127) Este mesmo fato foi verificado por outros historiadores, como Taunay, que se refere ao número crescente de expostos na segunda

(126) - A descontinuidade da documentação não permite uma reflexão precisa sobre os remédios encontrados pelas autoridades para estes casos. Dos mais complicados é o que se segue: "Diz o Cap.am Gabriel da Silva Souza Diniz assistente com seu negócio da fazenda seca na V.a de Itu, q' o R.do Fz. Pedro da Annunciação Chaves, q' ao prez. ${ }^{\text {te }}$ se acha também na d. ${ }^{a}$ V.a deo ao Sup.e sento, e sicoenta mil reis p. $^{a}$ lançar a benefício da liberdad.e da escrava Gertrtudes, q estava em Praça e como ella era cazada, lançou o Sup. no cazal: em a escrava p. a a sua liberdad.e pela comissão que tinha: em o escravo, p. ${ }^{a} \circ$ servir. $E$ estando nesta deligencia, se chegou a elle o Cap.am Jozé Manoel de Mesquita, e the dice q arrematasse aquele escravo $\mathrm{p}^{\mathbf{e}}$ elle, ao $\mathrm{q}$ o Sup. ${ }^{\mathrm{e}}$ nada respondeo, e continuou a lançar, e os rematou, fazendo de clarar nos termos, q a escrava Gertrudes foi rematada p. ${ }^{a}$ a sua Liberd. ${ }^{\mathbf{e}}$ e o escravo p $^{a}$ o servir. Concluindo isto, o R. ${ }^{\text {do }}$ Fz. Pedro, $\mathrm{q}$ assiste $\mathrm{em}$ as Cazas do falecido P. Estevão seo Tio, de q. ${ }^{m}$ forão estes escravos, despedio asperam. ${ }^{\text {te }} \circ$ marido daquella escrava, $q$ tinha libertado impondo-lhe preceito de não por mais péz em sua Casa, do q estimulado elle d.o marido, tratou de reduzir a m.er,.$^{\mathrm{a}}$ o acompanhar, $\mathrm{p}^{\mathrm{a}}$ a Caza do Sup. ${ }^{\mathrm{e}}$, de $\mathrm{q}^{\mathrm{m}}$ he ao prez.te escravo. Ao mesmo tempo o Cap. ${ }^{a m}$ José Manoel de Mesquita lhe quis dar o preso $\mathrm{p}^{\mathrm{r}}$ q. tinham rematado o d. ${ }^{\circ}$ escravo, $\mathrm{q} \cdot{ }^{\text {do }}$ já o Sup. ${ }^{\mathrm{e}}$ estava informado $\mathrm{q}$ aqueilo tinha de o possuir, hera por certos estimulos $q$ delle tinha, afim de se vingar; pelo q' the não quis vender: e por estes dois principios comesou o Odio a tecer tais enredos contra o Sup.e, q. se ve na necessidade de sair daquella terra, onde tem negocio avultado..." (Petição do Capitão Gabriel da Silva Souza Diniz. Itu, 1803, MS., Requerimentos sobre dívidas, heranças, queixa... (1721-1820), n. ordem 93, Cx. 341, Arquivo do Estado).

(127) - Marcílio, Maria Luíza. Crescimento demográfico..., pp. 157-158. 
metade do século XVIII, (128) e Laima Mesgravis, que, ao tratar do problema dos enjeitados na sociedade paulista, impressionou-se com as elevadas cifras de crianças expostas e ilegítimas. Até 1824, quando foi instalada a roda da Santa Casa, as percentagens oscilaram entre $17 \%$ e $25 \%$ dos batismos registrados. (129)

De fato, um levantamento feito, em termos de amostragem, discriminando os registros de batismos de escravos e de livres da Paróquia da Sé, revela os seguintes resultados:

\section{REGISTROS DE BATISMOS DA SÉ - ESCRAVOS E LIVRES - 130 REGISTROS \\ ESCRAVOS \\ (1775-1822) \\ (1782-1822)}

Pais declarados

Mãe declarada, pai incógnito

Pai declarado, mãe incógnita

Ambos os pais incógnitos

Filhos de criação

Adultos batizados

TOTAL
$383 \quad(29,74 \%)$
$872(67,70 \%)$
$10 \quad(0,78 \%)$
$1 \quad(0,08 \%)$
$22(1,70 \%)$
$1288 \quad(100 \%)$

$182(23,95 \%)$

$6 \quad(0,79 \%)$

$136(17,89 \%)$

$436 \quad(57,37 \%)$

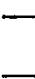

760

Estes dados são importantes à medida em que demonstram a situação de desvalimento em que se encontrava parte da infância de São Paulo. Apenas $29,74 \%$ dos escravos e $57,37 \%$ dos livres tinham a presumida assistência de seus pais, uma vez que a assunção da paternidade implicava a responsabilidade social pela prole. Ao lado desta infância protegida, encontravam-se as crianças com o semi-amparo representado pela declaração de apenas um dos progenitores, ou inteiramente desamparadas, os

(128) - Taunay, Affonso d'E. História da Cidade de Săo Paulo no século XVIII - 1735 - 1765. São Paulo, Coleção do Departamento de Cultura, 1949. V.I, 2. ${ }^{a}$ parte, pp. 107 e 136.

(129) - Mesgravis, Laima. A Santa Casa de Misericórdia..., p. 235.

(130) - Registros de batismos da Paróquia da Sé. Livros de escravos. 17751822, MS., Cúria Metropolitana de São Paulo. Livro de livres. 1782-1822. MS., Cúria Metropolitana de São Paulo. 
filhos de pais incógnitos. Ainda uma vez, o estudo da sociedade de São Paulo mostra zonas que poderiam ser abrangidas pela agregação: o desejo de se servirem de força de trabalho gratuita, a solidarieadde social ou espírito cristão levavam chefes a admitirem em suas casas crianças, que mais tarde convertiam-se em agregados à família que lhes dera abrigo.

As taxas elevadíssimas de ilegitimidade exigem algumas tentativas de explicação. A mera lassidão moral dos piratinganos, atestada desde os primeiros tempos, não é suficiente para esclarecer a legião de bastardos, germinada à sombra da família legalmente constituída.

Burguière tendo verificado significativo aumento da ilegitimidade nas cidades do século XVIII, pergunta se este fato seria indício claro de uma queda da moralidade ou de um aumento de marginalismos sociais. (131)

Essa alternativa de explicação parece bastante pertinente ao caso paulistano. A segunda proposta, ligada à pauperização sofrida pela sociedade do último quartel do século, é com certeza a mais viável, mesmo porque a primeira remeter-nos-ia a uma ordem de indagações (também proposta por Burguière) que leva a um impasse. Pode-se perguntar se o crescimento da ilegitimidade não seria devido, em parte, ao reforçamento da repressão, o que teria gerado um registro mais escrupuloso de paternidade. Nesta hipótese, teríamos que admitir uma sociedade anterior mais indulgente para com as transgressões da ordem conjugal. (132) Com efeito, os inventários e testamentos da época bandeirante deixam ver que a ortodoxia moral, esteada na Igreja, só em doutrina se mantinha. Ao lado da organização formal da família monogâmica, erguia-se toda uma organização clandestina, tacitamente tolerada. (133) Era comum incluírem-se cláusulas testamentárias em favor da prole extra-conjugal, não raro, por iniciativa das próprias esposas legítimas. (134) De modo geral, era o próprio pai que procurava amparar os filhos espúrios, através de fórmulas

(131) - "La démographie", in: Faire de l'histoire, p. 85.

(132) - Id., p. 87.

(133) - "Muito de persignação e genuflexão, muito de rezas com socos no peito, muito de orações nervosamente oferendadas a santos e, contudo, muito filho natural pelo lado das crenças ... Faltava aos membros do patriarcado rural a noção moral da família. Desta só possuiam a noção biológica, em cujas bases fatalmente haviam de tolerar a promiscuidade protegida pelo açúcar dos engenhos e pelas tulhas cafeeiras ... e, sobretudo, ungida pelas mãos austeras dos vigários, transigentes pelas côngruas e benessas". (Almeida, Fernando Mendes de. O folclore nas Ordenações do Reino, p. 40 e 42).

(134) - "Dise que deixava a sua enteada filha natural do seu marido por nome Juliana Favacho um rapaz por nome Valerio e hua rapariga por nome Sebastiana e que lhe dá de esmola dos bons servissos qua della tem recebido". (Inventário e testamento de Isabel de Barcelos, Vila de Santa Anna de Parnaíba, 1648, Inventários e Testamentos, v. XXXVI, p. 219). 
que os davam por havidos quando ainda solteiros, ou anteriores à ordenação, no caso de sacerdotes.

As declarações não pecavam pela prolixidade:

"Declaro que tenho um filho por nome Antonio e uma filha por nome Izabel havidos em solteiro que são mais herdeiros forçados (135);

"declaro que tenho dous filhos naturais avidos entempo de solteiro a saber Antonia Francisca moradora em Vilaboa de Goyazes e Antonio filho de Josefina Maria já falecida do qual se não sabe parte se esta onde asista nem se he vivo ou morto os quais tambem são meos Legitimos e forçados herdeiros". (136)

Os circunlóquios eram maiores no caso de padres, uma vez que seus filhos, considerados produtos de "damnado coito", não podiam suceder. (137)

Problemas de consciência ou astúcia revela a habilidade do Reverendo Padre Salvador de Oliveira Cardozo ao reconhecer dois filhos:

"Declaro que sendo eu ainda secular me nomearam por Pay de duas crianças que nem na Conceição, nem no parto ouve entre min, e ella empedimento algum..." (138)

e, mais adiante, prevenindo dúvidas que se pudessem originar sobre os direitos de seus filhos:

“... e tendo nesta materia alguns remorços, de conciencia, que me picavão propus a varios letrados, e sacerdotes doutos, se estes erão meus Erdeiros, ou não; os quais todos me dicerão una voce que erāo meus legitimos erdeiros, e a fazer eu o contrario me não podia salvar..." (139)

Estes exemplos dão a idéia de que os paulistas não ignoravam o direito de família e tinham consciência de suas transgressões. (140) A lei estatuía que para os homens do povo - os peões — os filhos ilegítimos poderiam

(135) - Testamento de Thomá Rodrigues Velho, São Paulo, 1660, Inventários $e$ Testamentos, v. XVI, p. 167.

(136) - Testamento do Alferes Antonio Paes Picanço, São Paulo, 15/6/1786, MS., Livro 3, fls. 110 v., cx. 455, Arquivo do Estado.

(137) - Almeida, Fernando Mendez de. op. cit., p. 116.

(138) - Testamento do Reverendo Pe. Salvador de Oliveira Cardozo, São Paulo, 3/7/1756, Ms., Livro 3, fls. 74. Arquivo do Estado.

(139) - Id., Ibid., fls. 75.

(140) - "Declaro que em solteiro tive húa filha natural por nome Valeriana, a qual por leis do Reino, visto os cargos honrrosos que servi e pela nobreza que aqueri e meu filho legítimo acha que não pode ser herdeira..." (Inventário de Manoel Frz' de Morais, Vila de São Paulo, 1646). 
ser equiparados aos legítimos, desde que fossem de leito de mulher solteira, não impedida por parentesco e se tratasse de "huma só manceba". (141) Para os nobres, as coisas se complicavam, traduzindo-se em regras minuciosas de sucessão. Na carta de Doação da Capitania de São Vicente, a preferência era para os descendentes legítimos, os machos primeiros. $\mathrm{Na}$ falta de filhos legítimos, os bastardos, não sendo "de damnado coito", poderiam herdar desde que o Donatário não quisesse legar seus direitos a parentes transversais. (142)

A classificação da prole, tal como se pode ver pelos registros de batismos e em documentações paralelas, pode ser assim sintetizada: legítima, quando nascida de casal unido matrimonialmente; ilegítima, havida fora do matrimônio e compreendendo os filhos naturais e os espúrios. Naturais, quando provenientes de homem e de mulher sem impedimento matrimonial; espúrios, na hipótese de impedimentos na época da concepção, caso em que os filhos eram adulterinos ou incestuosos. (143)

A máxima de que "a maternidade é um fato, a paternidade uma presunção", atingia extensão inusitada no meio paulista, com alguns casos pitorescos de "maternidades presumidas" registrados em batismos de filhos de mães incógnitas, com pais declarados.

Paulo Eiró transplantou para o teatro esse aspecto social de São Paulo, ao fazer uma de suas personagens, Vitorino, dizer em certa passagem de Sangue limpo:

“D. Luísa, está vendo aquele sujeito pimpão, que ali passa com o chapéu amarrotado e uma casaca do tempo de Martim Afonso? ... Sem mais nem menos é aquele a quem devo a honra de vir a este mundo, posto que por decência chamem-me filho de pais incógnitos. $O$ que há muito nesta terra são pais de filhos incógnitos, semeadores que não colhem. Este bom velho creio que nunca pensou na minha existência, e eu deixo ficar a coisa assim, porque não desejo herdar o seu chapéu amarrotado, nem a sua casaca decrépita". (144)

Nos livros de batizados da Paróquia da Sé, são excepcionais as notações de filhos dados como legítimos. A grande maioria refere-se simplesmente a filho de fulano e de sua mulher sicrana, subentendendo filiação legítima. Amiúde aparecem os filhos de pais incógnitos, os expostos e os

(141) - Almeida, Fernando Mendes de, op. cit., p. 116.

(142) - Madre de Deus, Frei Gaspar da. Memórias para a História da Capitania de São Vicente, p. 158-159.

(143) - Monteiro, Washington de Barros. Curso de Direito Civil. Direito de Família. 5.a ed. São Paulo, Ed. Saraiva, 1962, p. 251.

(144) - P. 39. 
de mãe declarada e de pai incógnito. Portanto, os nascimentos estavam subordinados a três categorias principais: $1 .^{2}$ ) ambos os pais declarados, não ficando taxativamente determinada a legitimidade, a não ser em casos raríssimos; $2 .^{a}$ ) pai incógnito ou incerto e mãe declarada; $3 .{ }^{a}$ ) ambos os pais incógnitos. (145)

Em 2828 casos pesquisados, a partir de quatro livros de registros, foram conseguidos os seguintes dados: (146)

REGISTROS DE BATISMOS DA PARÓQUIA DA SE - Livros 1, 2, 3 e 5

$\begin{array}{ccccc}\text { Livros } & \begin{array}{c}\text { Pais } \\ \text { declarados }\end{array} & \begin{array}{c}\text { Mãe declarada, } \\ \text { pai incógnito }\end{array} & \begin{array}{c}\text { Pais } \\ \text { incógnitos }\end{array} & \begin{array}{c}\text { N. }{ }^{\circ} \text { de } \\ \text { casos }\end{array} \\ 1 & 77 & 35 & 46 & 158 \\ & 48,73 \% & 22,16 \% & 29,11 \% & 100 \% \\ 2 & 442 & 55 & 98 & 595 \\ 3 & 74,29 \% & 9,54 \% & 16,47 \% & 100 \% \\ & 702 & 133 & 165 & 1000 \\ & 70,20 \% & 13,30 \% & 16,50 \% & 100 \% \\ & 553 & 210 & 212 & 975 \\ \text { TOTAIS } & 1774 & 21,54 \% & 21,74 \% & 100 \% \\ & 65,03 \% & 433 & 521 & 2728 \\ & & 15,87 \% & 19,10 \% & 100 \%\end{array}$

$\mathrm{Na}$ categoria de mães declaradas e pais incógnitos ou incertos, surgem os seguintes tipos: solteira forra, parda forra, agregada solteira, viúva, bastarda solteira, solteira parda forra e, simplesmente, forra.

A desorganização familiar, expressa em nascimentos ilegítimos, desdobrava-se no problema social gravíssimo das crianças abandonadas, advertido por Castro e Mendonça em pasagem memorável na qual se refere aos

(145) - Registro de batizados da Paróquia da Sé, MS., Livros 1, 2, 3 e 5, Armário 2, Prateleira 2, Arquivo da Cúria Metropolitana de São Paulo.

(146) - A falta de sistematização nos registros de batismos (o livro n. I, por exemplo, refere-se ao período de 1783-1784, enquanto que o de n. 2 ao de 13/11/1740 a 24/1/1750), filiada ao mau estado dos documentos, torna impraticável uma análise quantitativa rigorosa. De todos os livros compulsados, o de n. 3 é o que está em melhor estado, com apenas vinte e cinco registros ilegíveis. Os outros apresentam-se bastante danificados, como o de n. 2 onde há 1158 registros, com apenas 595 plenamente legíveis e o de n. 5 onde, para um total de 1176 casos contam-se 201 registros ilegíveis. 
"innocentes cujo nascimento as circunstancias de suas Mays obriga occultar", causa de muitos infanticídios e do abandono a portas de particulares, sendo poucos os que escapavam aos maus tratos desses. (147)

É conveniente analisar alguns motivos que levariam os pais ao abandono dos filhos.

O primeiro deles - por certo não o mais importante - prendia-se à clandestinidade da procriação realizada fora do casamento. $O$ trecho acima transcrito refere-se particularmente a esse fato.

A frequiência de nascimentos situados fora dos padrões socialmente desejáveis, não lhes retirou a pecha moral. É o que diz a documentação, como o caso narrado por Juzarte sobre a filha de um povoador de Iguatemi, a qual ocultou a sua gravidez até o momento do parto, escapando depois, a custo, de ser morta por seu pai e irmãos. (148)

A condenação de filhos havidos fora do casamento era mais rígida entre os brancos. Uma análise de dados referentes a crianças expostas deixa esse fato bastante claro: em 1765, dos 77 expostos arrolados, 74 eram brancos e apenas 3, mulatos. (149)

As crianças abandonadas na cidade de São Paulo, "os infelizes órfãos brancos" que aí seriam em maior número do que em qualquer outra parte do Brasil, no testamento do Visconde de Congonhas do Campo, em 1825, (150) não se compunham apenas de expostos, nome este que parece ter

(147) - Mendonça, Antonio Manoel de Meilo Castro e "Memória econômico política da Capitania de São Paulo", Anais do Museu Paulista, v. XV, 1961, p. 103-104.

(148) - "No mesmo dia dez de Abril de tarde ... sucedeu que uma filha de um povoador solteira se achasse também pejada cujo fato ocultava a seu pai e a sua mãe e a seu irmão, os quais eram de natureza de terem pouco escrúpulo de matar gente, pois destes há muitos por esta Capitania; isto suposto não podendo a dita moça sofrer dores do parto, nem retirar-se para parte alguma, pariu publicamente no meio, e à vista do tanto povo acudindo-lhe somente de um lado sua mãe e de outro uma bastarda que assistiu a hora do parto.

Estando as coisas nesta figura me vi obrigado a prender o pai, e irmãos da dita moça e a ela fazê-la conduzir com sua mãe, e a bastarda, para um rancho que na praia do Rio se achava, o qual me vi obrigado a cercar com sentinelas e um inferior para impedir todo o acesso, e brutalidade daqueles homens, e seus sequasas que por mais partidos que se lhe fizessem a nada atendiam". In: Juzarte, Theotonio Joze - "Diário da Navegação do Rio Tietê, Rio Grande Paraná, e Rio Egatemy ... e de tudo o acontecido neste Diario pelo tempo de dous mezes que principio em 10 de março de 1769" (Revista do Arquivo Municipal, v. LXI, 1939, p. 82).

(149) - Maças de população da cidade de São Paulo, ano de 1765.

(150) - Relatório do Visconde de Congonhas do Campo, 1/10/1825, apud Morse, Richard. "Raízes oitocentistas da Metrópole", Anais do Museu Paulista, v. XIV, p. 460. 
sido atribuído especialmente às crianças ilegítimas abandonadas. (151) Há menção a pelo menos mais dois tipos: "enjeitados" e "órfãos". Ainda uma vez a carência dos registros impede uma visão global do processo e as várias categorias acabam incluindo-se no esquema panorâmico da infância abandonada.

Além do peso da censura de ordem ética que pressionava os comportamentos, outros fatores devem ser considerados no quadro dos motivos em razão dos quais os pais abandonavam os filhos.

Havia a pobreza dos casais que, não podendo limitar os nascimentos, limitavam seus encargos de família. (152) E admissível que parte das crianças dadas por ilegítimas fossem na verdade simples produtos da miséria, que, mais do que a má conduta, seria responsável pelos abandonos. Para São Paulo parece serem aplicáveis as conclusões a que Gutton chegou em seu estudo sobre os pobres de Lyon, vendo que as dificuldades econômicas ligadas à indigência do mercado de trabalho, levariam os pais a abandonar os filhos. (153)

Expostas, enjeitadas ou órfãs, as crianças abandonadas em São Paulo formavam uma certa mão-de-obra prospectiva. Neste aspecto, a agregação desempenhou função dupla: social, ao impedir que parte da infância abandonada resvalasse para a vagabundagem e econômica, ao garantir aos moradores a força de trabalho gratuita dos homens livres desvlidos. (154)

(151) - Os recenseamentos de época mostram que os expostos eram quase sempre brancos. Quanto aos enjeitados, notados em número pequenos nos recenseamentos, Kidder afirma que muitos deles eram filhos de escravos cujjos senhores "não querendo ter trabalho nem fazer gastos com a criação dos negrinhos, ou precisando das mães para amas, obrigam-nas a abandoná-los na 'enjeitaria' de onde, se sôbre-viverem, sairão libertos" (Kidder, Daniel P. Reminiscências de viagens $e$ permanências no Brasil (províncias do Sul), São Paulo, Martins Ed. / EDUSP, 1972, p. 61). p. 89 .

(152) - Observação também feita por Burguière, André in: "La démographie",

(153) - La société et les pauvres, p. 130.

(154) - De passagem, diga-se que o mecanismo social do abandono de crianças parece ser crônico na história paulista. A $7 / 5 / 75$, p. 17 o Jornal da Tarde (S. Paulo) publicou uma reportagem a respeito das crianças abandonadas pelos pais, chamadas de "expostas" pelas autoridades e deixadas ora num banco de igreja, ora no meio de uma praça, ora dentro de um automóvel ou de um ônibus, por pais muitas vezes demasiadios pobres para criá-las. 